\title{
10. DIAGENESIS OF THE UPPER JURASSIC-LOWER CRETACEOUS CARBONATE PLATFORM OF THE GALICIA MARGIN AT OCEAN DRILLING PROGRAM SITE 6391
}

\author{
Maria M. Daniel and Janet A. Haggerty, Department of Geosciences, University of Tulsa, Tulsa, Oklahoma
}

\begin{abstract}
Upper Jurassic (Tithonian)-Lower Cretaceous limestone and dolomite were cored at Site 639 during ODP Leg 103. The purpose of the leg was to recover strata and basement documenting the rifting evolution of the Atlantic Iberian margin. The six drill holes of Site 639 are interpreted as a sampling of different stratigraphic levels at the edge of a fault block. Recovered carbonate strata are divided into two units: the lower unit consists of limestone with interbedded sandstone and claystone; the overlying unit is dolomite.

The lower limestone unit indicates a transition from a low-energy, shallow-water, nearshore environment to a more seaward, shelf environment. Dolomite in the upper strata is associated with stylolites. This unit also has fractures filled with dolomite that have a cathodoluminescence and chemistry similar to that of the overlying dolomite unit.

The dolomite unit is characterized by overall low iron and high sulfur contents, which suggests an oxidizing environment of formation. The upper strata contain vugs and fractures lined with baroque dolomite and typically filled with detrital dolomite and argillaceous material. The unit also has some rhombohedral dolomite crystals with cloudy cores and clear rims. Cathodoluminescence and microprobe analyses of these two crystal morphologies document the formation of these crystals in shallow burial conditions associated with hypersaline brines. The relatively high strontium content in these rocks does not support the formation of the dolomite in a mixing zone, or meteoric environment.
\end{abstract}

\section{INTRODUCTION}

Site 639 of Ocean Drilling Program (ODP) Leg 103 is on the up-tipped edge and upper slope of the escarpment of a tilted fault block (Fig. 1), one of a series of similarly oriented fault blocks that formed during rifting of the Galicia margin from Newfoundland. These blocks appear as a sequence of steps ascending from the eastern North Atlantic Basin up the outer part of the Galicia margin on the northern Iberian continental margin.

Strata recovered at Site 639 record the evolution of the Galicia margin from a pre-rift shallow-water carbonate platform that subsequently subsided to form a syn- and post-rift basinmargin environment. This chapter describes the petrology and geochemistry of diagenetic features observed in the dolomitized carbonate platform and the interpreted diagenetic environments responsible for the dolomitization.

Site 639 is in a water depth of approximately $4740 \mathrm{~m}$. Difficult drilling conditions in fractured and brecciated dolomite resulted in the drilling pipe sticking in the holes before the limestone section of the carbonate platform was reached, which resulted in abandonment. Hole 639D was the only hole abandoned for a different reason, owing to bit failure; it was the only hole that penetrated the limestone section of the carbonate platform. The Site 639 holes form an 800-m-long east-west transect of the margin from the easternmost hole (639A) in $4720 \mathrm{~m}$ water depth to the westernmost hole $(639 \mathrm{~F})$ in $4754 \mathrm{~m}$ water depth.

Strata from six lithologic units were recovered from the six holes drilled at Site 639. The emphasis of this study is on the strata designated as Units III, IV, and V (Shipboard Scientific Party, 1987). Unit III, recovered only in Hole 639A from a depth of 21.6 to $70.3 \mathrm{~m}$ below seafloor (mbsf) (Samples 103$639 \mathrm{~A}-4 \mathrm{R}-1,10 \mathrm{~cm}$, to $103-639 \mathrm{~A}-8 \mathrm{R}, \mathrm{CC}$ [7 cm]), is mottled pale yellow marlstone of Valanginian age. Unit IV is dolomite recovered from Holes 639A through 639D at various sub-bottom

\footnotetext{
${ }^{1}$ Boillot, G., Winterer, E. L., et al., 1988. Proc. ODP, Sci. Results, 103: College Station, TX (Ocean Drilling Program).
}

depths. Unit V, recovered in Hole 639D from 199 to $293.1 \mathrm{mbsf}$, is Upper Jurassic clayey limestone, marlstone, and sandstone. The strata from Units III, IV, and V dip to the east and crop out on the submarine erosion surface on the western side of the fault block. Neogene pelagic ooze onlaps this side of the block.

Units IV and V are interpreted from seismic-reflection data as forming the upper surface and layers of the tilted fault block. These sediments were deposited prior to faulting and rifting of the Newfoundland-Iberian margin during the development of the North Atlantic Basin (Jansa and Wade, 1975) and, therefore, are classified as pre-rift strata. The depositional environments associated with these pre-rift units should reflect the tectonics of the North Atlantic Iberian margin prior to rifting. Core recovery is very low in Units IV and V, ranging from $3 \%$ to $32 \%$, because of the drilling difficulties. Petrographic and geochemical data on the diagenetic features from the dolomitized carbonate platform, as well as the interpretations presented in this chapter, are limited by the poor recovery.

\section{METHODS}

Representative samples were selected from a survey of the distribution of fracture fills and textural changes in the dolomitized carbonate. Mineralogy of cements, fracture fills, and the bulk rock was determined by X-ray diffraction using a Norelco diffractometer with a high-energy Ni-filtered, $\mathrm{Cu}-\mathrm{K}_{\alpha}$ source and by standard staining techniques (Friedman, 1971). Observations with a Coates and Welter scanning electron microscope (SEM) revealed details of the morphology of the dolomite crystals.

Cathodoluminescence microscopy was used to investigate cement stratigraphy, and blue-violet fluorescence microscopy was used to reveal the relic microstructure of altered bioclasts, thereby aiding identification of fauna or flora in the dolomite unit. Cathodoluminescence is produced by the emission of light during electron bombardment, whereas fluorescence is produced from a longer wavelength of light than the wavelength of the excitation light. Different colors of luminescence appear if there is an appropriate variation in the trace element chemistry of a crystal or the abundance of fluid or solid inclusions within a crystal or from differences in mineralogy.

Electron microprobe analysis was used to determine variations in the chemical composition of the host rock and cement stratigraphy associated with fracture fills and dolomite rhombohedra. For analysis of dolomite and calcite, polished thin sections were coated with silver follow- 


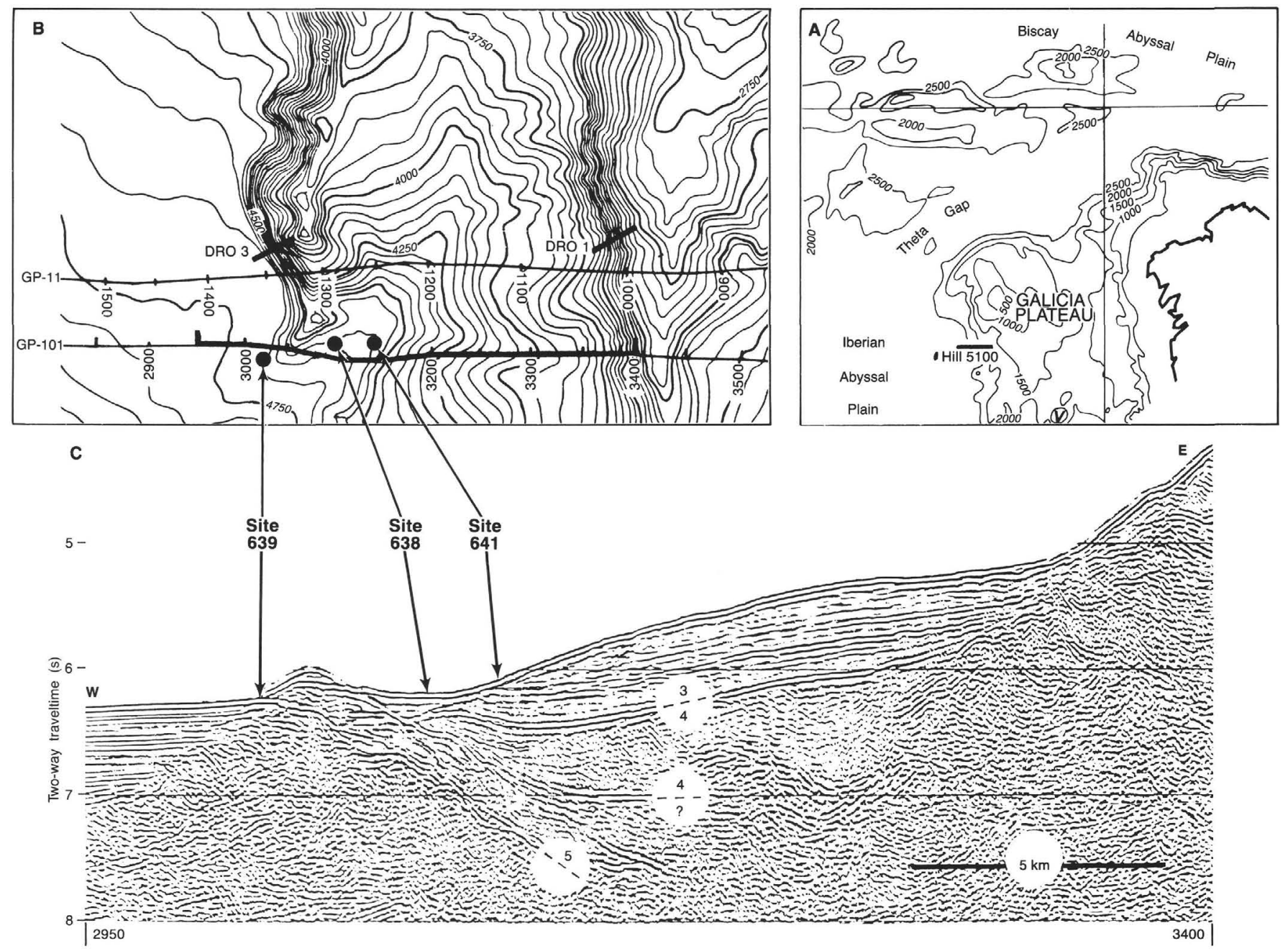

Figure 1. A. Map of Galicia margin with location of ODP Leg 103 drilling transect shown as a thick line. B. Sea Beam map showing detailed bathymetry in the area of the drill sites. C. Seismic profile showing location of Sites 638, 639, and 641. Note Site 639 is on the western escarpment of the fault block.

ing the method of Smith (1986) to inhibit thermal decomposition of the carbonates during electron bombardment. An ARL five-spectrometer electron microprobe with a $1-\mu \mathrm{m}$ focused beam was operated at an accelerating potential of $20 \mathrm{kV}$ and a sample current of $10 \mathrm{nA}$ for calcite analysis and $20 \mathrm{nA}$ for dolomite analysis. For analyses of calcite in Sample 103-639D-5R-2, 124-128 cm, counting times on the peak, as well as on the high and low background sides of the peak, were $10 \mathrm{~s}$ for $\mathrm{Ca}, \mathrm{Mg}, \mathrm{S}$, and $\mathrm{Na}, 20 \mathrm{~s}$ for $\mathrm{Fe}$ and $\mathrm{Mn}$, and $60 \mathrm{~s}$ for Sr. For analyses of the baroque dolomite in Sample 103-639A-8R, CC $(6-11 \mathrm{~cm})$, counting times on the peak and high and low background sides were $10 \mathrm{~s}$ for $\mathrm{Ca}$ and $\mathrm{Mg}, 150 \mathrm{~s}$ for $\mathrm{S}$ and $\mathrm{Na}$, and $160 \mathrm{~s}$ for $\mathrm{Fe}, \mathrm{Mn}$, and $\mathrm{Sr}$. For analyses of the rhombohedral dolomite in Sample 103-639D-2R, CC (5-7 cm), counting times on the peak and high and low background sides were $10 \mathrm{~s}$ for $\mathrm{Ca}$ and $\mathrm{Mg}, 200 \mathrm{~s}$ for $\mathrm{S}$ and $\mathrm{Na}$, and $210 \mathrm{~s}$ for $\mathrm{Fe}, \mathrm{Mn}$, and $\mathrm{Sr}$.

Preparation of the samples for microprobe analysis and the electron microprobe operating conditions used in this study differ from most microprobe studies of carbonates for several reasons:

1. Coating carbonates with silver instead of carbon permits the use of higher sample currents, a focused beam, and longer counting times without thermally decomposing the sample.

2. The $1-\mu \mathrm{m}$ focused beam is more than an order of magnitude smaller than the diffuse beam used in other carbonate studies, which enhances spatial resolution.

3. Long counting times are used for trace element analyses- $5 \mathrm{~min}$ on the peak and $10 \mathrm{~min}$ total on the background $(5 \mathrm{~min}$ on each side of the peak) - of the rhombohedral dolomite. These long counting times lower the detection limits for trace elements in carbonate rocks (Smith, 1986).

4. $\mathrm{Sr}-\mathrm{L}_{\alpha}$ is analyzed on the TAP crystal instead of the PET crystal. The Sr- $\mathrm{L}_{\alpha}$ peak on a TAP crystal occurs near the lower limit of the wavelength spectrometer, providing maximum intensity of $\mathrm{X}$-rays and the lowest detection limits. The Sr- $\mathrm{L}_{\alpha}$ peak on the PET crystal occurs on the upper limit of the wavelength spectrometer; thus, the intensity of the $\mathrm{X}$-rays is extremely attenuated because the distance between the sample and the diffracting crystal is larger.

Microprobe detection limits for each of the elements were calculated by tripling the square root of the background counts of the analyzed element. Detection limits for elements analyzed in the calcite are $180 \mathrm{ppm}$ $\mathrm{Ca}, 320$ ppm Mg, 190 ppm Fe, 250 ppm Mn, 500 ppm Na, 90 ppm Sr, and $130 \mathrm{ppm}$ S. Detection limits for elements analyzed in the baroque dolomite are $160 \mathrm{ppm} \mathrm{Ca}, 370 \mathrm{ppm} \mathrm{Mg}, 60$ ppm Fe, 80 ppm Mn, 90 ppm Na, $160 \mathrm{ppm} \mathrm{Sr}$, and $30 \mathrm{ppm}$ S. Detection limits for elements analyzed in the rhombohedral dolomite are $130 \mathrm{ppm} \mathrm{Ca}, 340 \mathrm{ppm} \mathrm{Mg}, 50$ ppm Fe, 60 ppm Mn, 70 ppm Na, 140 ppm Sr, and 30 ppm S. All graphs of the microprobe data have an analysis error bar equivalent to one standard deviation of the elemental concentration and a thick horizontal line indicating the detection limit for that data set.

In the data tables, average elemental concentrations in ppm have been calculated for cathodoluminescent zones analyzed by the electron microprobe. These tables are similar to the type of information obtained from broad-beam analyses of carbon-coated carbonates. Averages are calculated from all analyses within the zones, regardless of 
whether the analysis was above or below the detection limit for that element. Therefore, the average elemental concentration values may fall below the detection limit for that element. One standard deviation from the mean is given with these averages to indicate the degree of variability within the data set.

\section{DEPOSITIONAL ENVIRONMENTS}

The environment of deposition of the units forming the tilted block was determined petrographically by identification of bioclasts and nonskeletal grains. The interpretation of the depositional environment of Unit IV (Samples 103-639A-8R, CC [7 cm] to $103-639 \mathrm{~A}-10 \mathrm{R}-2,125 \mathrm{~cm}$; 103-639B-2R-1, $0 \mathrm{~cm}$, to $103-639 \mathrm{~B}-$ $4 \mathrm{R}, \mathrm{CC}[20 \mathrm{~cm}] ; 103-639 \mathrm{C}-2 \mathrm{R}-2,41 \mathrm{~cm}$, to $103-639 \mathrm{C}-2 \mathrm{R}-2$, $102 \mathrm{~cm}$; and 103-639D-2R, CC [0 cm] to 103-639D-4R-1, $9 \mathrm{~cm}$ ) is more subjective than that of Units III (Samples 103-639A$4 \mathrm{R}-1,10 \mathrm{~cm}$, to $103-639 \mathrm{~A}-8 \mathrm{R}, \mathrm{CC}[7 \mathrm{~cm}]$ ) and V (Samples 103639D-4R-1, $9 \mathrm{~cm}$, to 103-639D-13R, CC [36 cm]) because it has extensive dolomitization. However, identification of some fossil ghosts and the stratigraphic relationship of the units suggest the depositional environment of Unit IV.

The interpretation of the environment of deposition of Unit $\mathrm{V}$ encompasses a lower limestone facies (Cores 103-639D-9R through 103-639D-13R), a transitional clayey limestone facies interbedded with sandstones and claystones (Cores 103-639D6R through 103-639D-8R), and an upper clayey limestone facies (Cores 103-639D-4R through 103-639D-5R). On the basis of paleontologic data (see "Biostratigraphy" section in "Site 639" chapter; Shipboard Scientific Party, 1987), this unit is as young as Tithonian.

The depositional environment of the lower strata of Unit V is evidenced by the limestones as well as the interbedded clastics and gradational facies. Peloidal and oncolitic limestones indicate a shallow-water, low-energy depositional environment, and the texturally and compositionally immature sandstones indicate a proximal continental source. Thus, together the limestones, the interbedded sandstones and claystones, and the gradational facies indicate a nearshore depositional environment.

The upper strata (Cores 103-639D-4R through 103-639D-5R) consist of clayey skeletal wackestones with interbeds of marlstone, calcareous silt, and silty clay in Core 103-639D-5R. These strata are distinct from the lower strata because of the general lack of low-energy, nonskeletal carbonate grains and coarse terrigenous clastics. The bioclasts are also more diversified than those in the lower strata (see Jansa et al., this volume, for taxa identification). Abundant micrite interspersed with the bioclasts suggests that the facies may be the expression of a mud mound or back-reef environment in which the organisms locally stabilized or trapped sediment. The microfacies of Unit $\mathrm{V}$ indicates that the depositional environment of the upper strata was in deeper water than that of the lower strata, but remained within the shelf environment.

Interpretation of the depositional environment of the dolomite (Unit IV) requires identification of fossil ghosts. The preservation of benthic foraminifers, bryozoans, sponges, red algae, corals, bivalves, gastropods, and oncoids is suggested by relict microstructures observed using standard petrographic techniques. Echinoderms present are recognizable petrographically by syntaxial overgrowths and serate pore patterns forming crystals that are both larger and more oblate than the host dolomite crystals (Fig. 2). However, their abundance may be a misrepresentation of their preservation through diagenesis.

An ostracode is revealed by fluorescence petrography using a blue-violet wavelength on Sample 103-639A-10R-1, 41-44 cm (Fig. 3). Ghosts of benthic foraminifers and another ostracode are also revealed by fluorescence petrography in Sample 103639A-10R-2, 16-21 cm. The ostracodes appear to have a smooth ornamentation that may indicate a low-energy environment. The benthic foraminifers are identified as Dorothia sp. (Fig. 4) af-

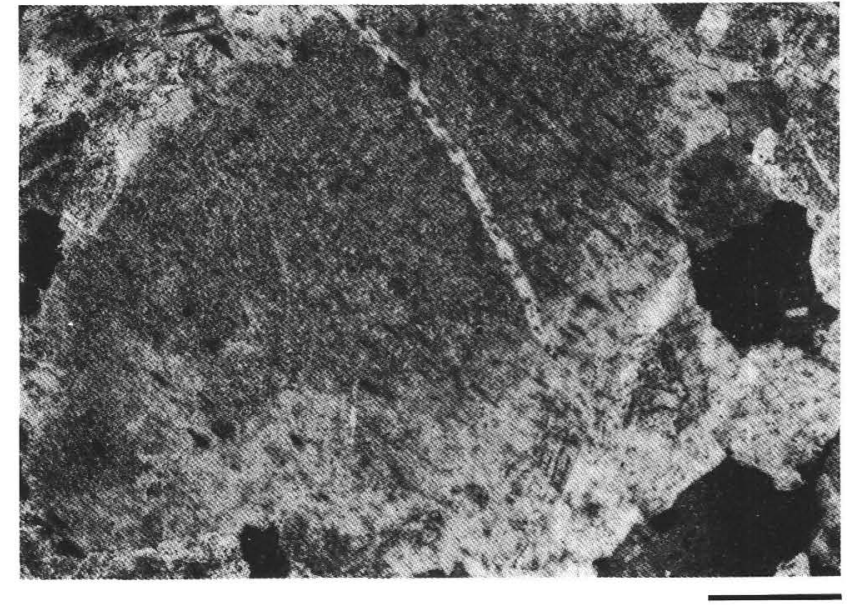

Figure 2. Echinoderm enclosed by dolomite mosaic (Sample 103-639A$10 \mathrm{R}-1,32-35 \mathrm{~cm}$ ). Scale bar represents $0.5 \mathrm{~mm}$. Crossed nicols.

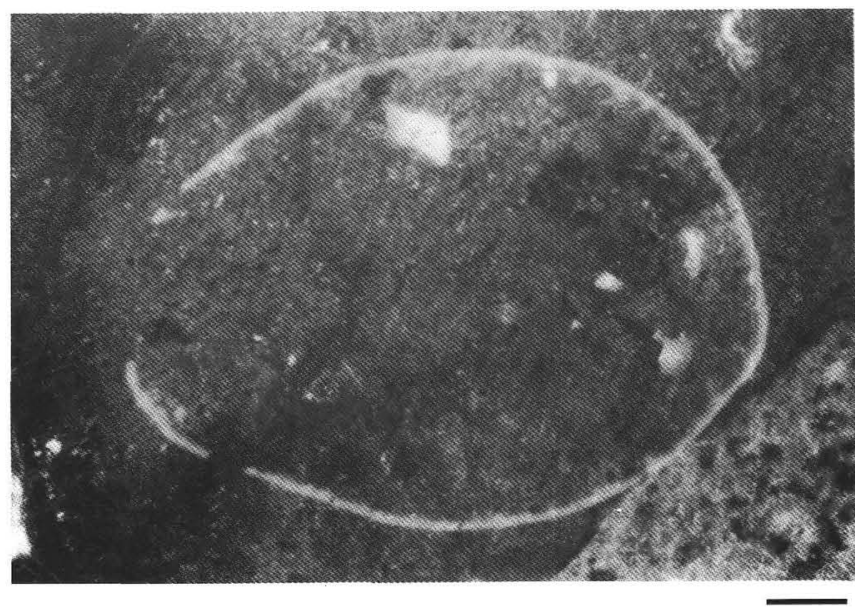

Figure 3. Ostracode within the host dolomite of Unit IV (Sample 103639A-10R-1, 41-44 cm). Scale bar represents $0.1 \mathrm{~mm}$. Blue-violet fluorescence.

fined to $D$. cornula (Reuss) and a trochamminid (Fig. 5). These are neritic or upper bathyal forms (Sliter, 1980) that may be as young as Valanginian (W. Sliter, pers. comm., 1987). On the basis of stratigraphic superposition and this biostratigraphic data, Unit IV may range in age from late Tithonian through Valanginian. Overall, the recognizable bioclasts suggest a low-energy, shelf depositional environment for Unit IV.

Unit III is dominantly marlstone containing nannofossils, calpionellids, foraminifers, and the planktonic crinoid Saccocoma. The biostratigraphic zonation of the planktonic microfossils and the lithology and type of benthic foraminifers indicate a Valanginian bathyal environment (see "Biostratigraphy" section in "Site 639" chapter; Shipboard Scientific Party, 1987). Although the transition between the depositional environments of Units III and IV appears to be rather abrupt, the contact between the two units was not recovered.

\section{DIAGENETIC FEATURES OF UNITS IV AND V}

\section{Petrography}

The diagenetic history of the units forming the tilted block may be documented petrographically. The dolomite of Unit IV 


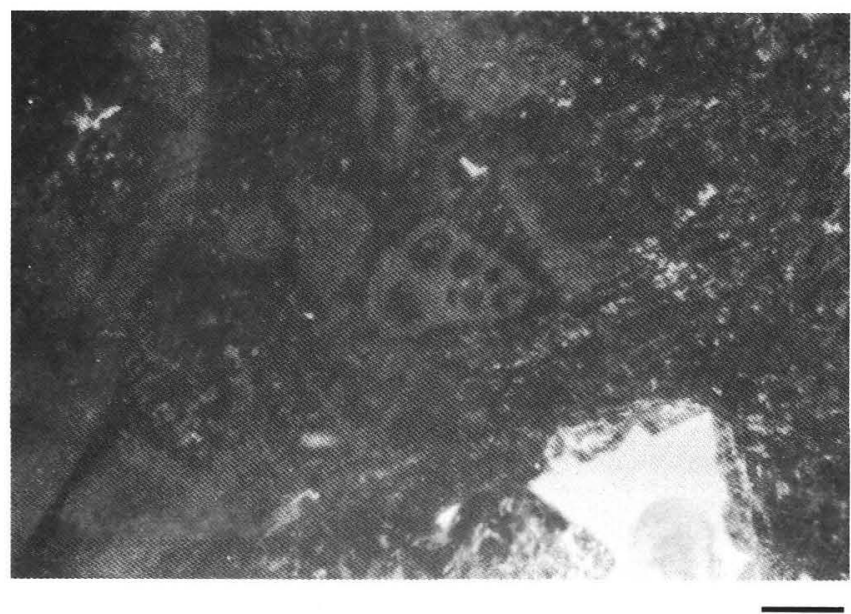

Figure 4. Benthic foraminifer identified as Dorothia sp., Unit IV (Sample 103-639A-10R-2, 16-21 cm). Scale bar represents $0.1 \mathrm{~mm}$. Blue-violet fluorescence.

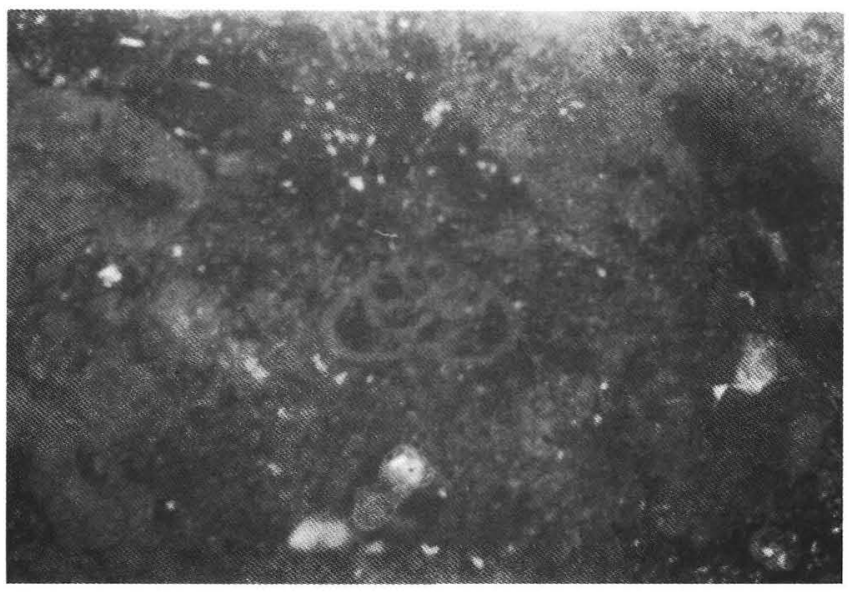

Figure 5. Trochamminid in Unit IV (Sample 103-639A-10R-2, 16-21 cm). Scale bar represents $0.1 \mathrm{~mm}$. Blue-violet fluorescence.

is characterized by different crystal textures that may reflect the diagenesis of the unit. The dolomite host grades from xenotopic crystals (Gregg and Sibley, 1984) rich in impurities to rhombohedral crystals with cloudy cores and clear rims. Dolomite veins and neomorphic features are present in Unit V.

\section{Unit IV}

The anhedral dolomite crystals are the dominant morphology and develop a crystalline mosaic. The turbid dolomite host also encompasses dolomitized, clear syntaxial overgrowths on echinoderm debris (see Fig. 2). Although euhedral dolomite is less common, rhombohedral turbid cores indicate that the euhedral form may not have endured the competition for growth space with surrounding crystals (Fig. 6).

The upper strata of the dolomite are rich in vugs of varying sizes. The larger vugs, most pervasive in material recovered from Hole 639A, are lined with clear, drusy dolomite crystals. Some of the vugs are filled with geopetal internal sediment composed of detrital dolomite and argillaceous material and commonly laminated (Fig. 7), indicating more than one episode of deposition.

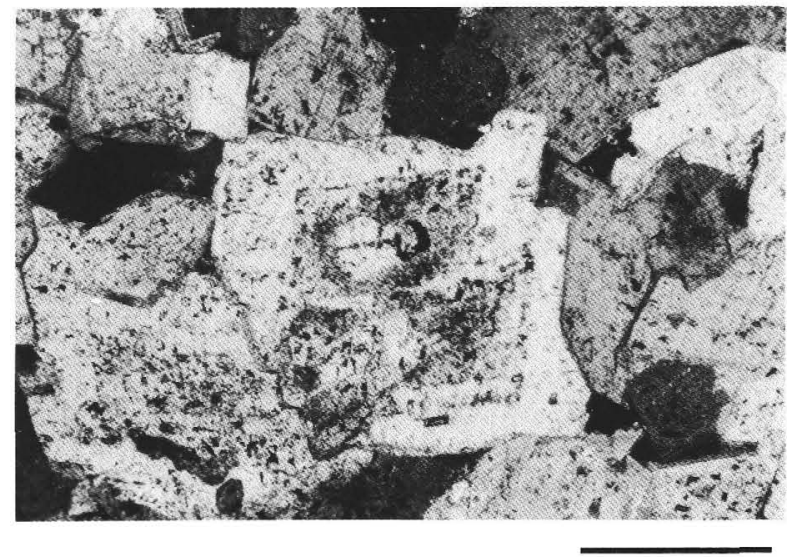

Figure 6. Rhombohedral turbid cores in anhedral dolomite (Sample 103639A-9R-1, 4-9 cm). Scale bar represents $0.25 \mathrm{~mm}$. Crossed nicols.

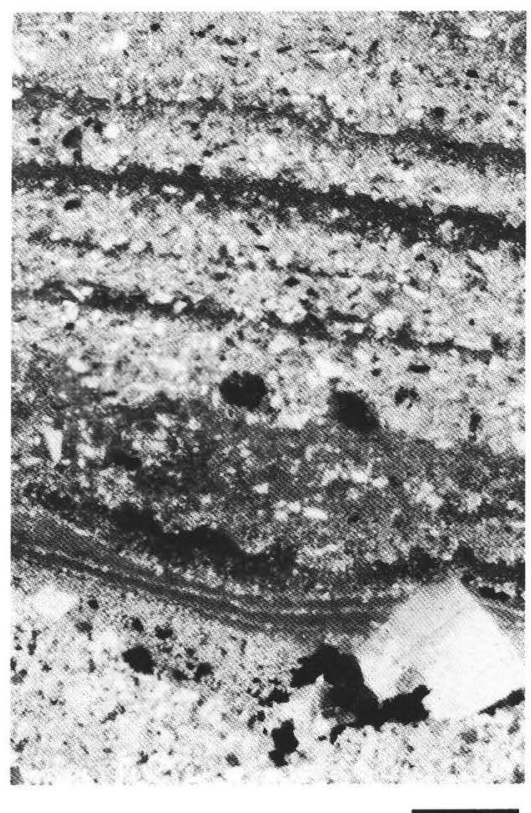

Figure 7. Laminated internal sediment (Sample 103-639A-10R-2, 45$47 \mathrm{~cm}$ ). Scale bar represents $1 \mathrm{~mm}$. Crossed nicols.

The dolomite unit is characterized by crosscutting fractures that exhibit offset. The offset is evidence of at least two fracturing events. The fractures vary in width, with clear dolomite crystals sparsely lining the wider fractures. Clear dolomite veins present in the unit are interpreted to have formed initially as fractures, as the clarity of the dolomite suggests that the crystals were formed in a void. These fractures may have been sufficiently narrow to allow the clear dolomite to fill them (Figs. 8A and $8 \mathrm{~B}$ ). Internal sediment similar to the geopetal infill in the vugs generally fills the wide fractures and is occasionally laminated.

The crystals forming the clear veins and lining the wide fractures exhibit a similar morphology. The clear veins and fractures are dominated by rectangular crystals with straight edges. However, areas of the clear veins are formed of crystals that are intergrown and exhibit curved crystal boundaries (see Fig. 8A). Crystals with curved crystal boundaries also line the wider fractures (Fig. 9). The similar crystal morphologies in the veins and fractures indicate that the wider fractures formed as clear veins 


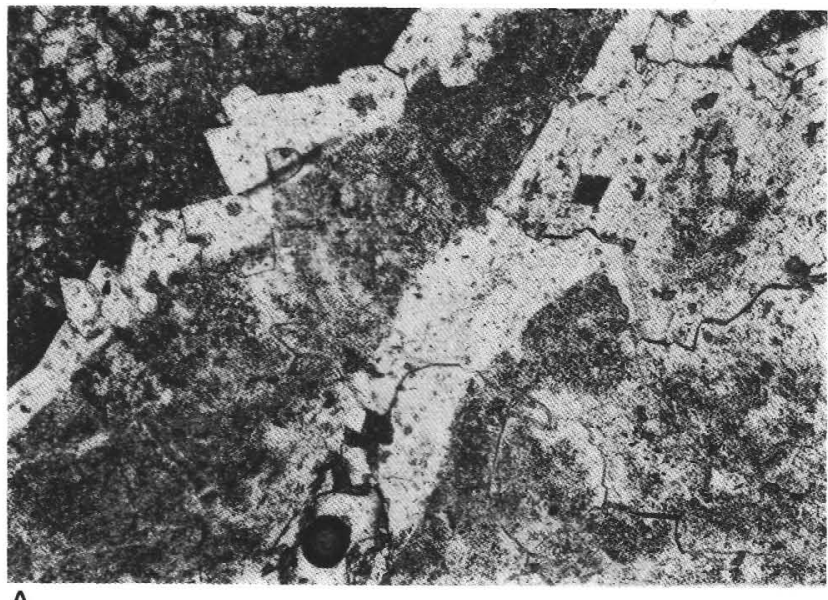

A

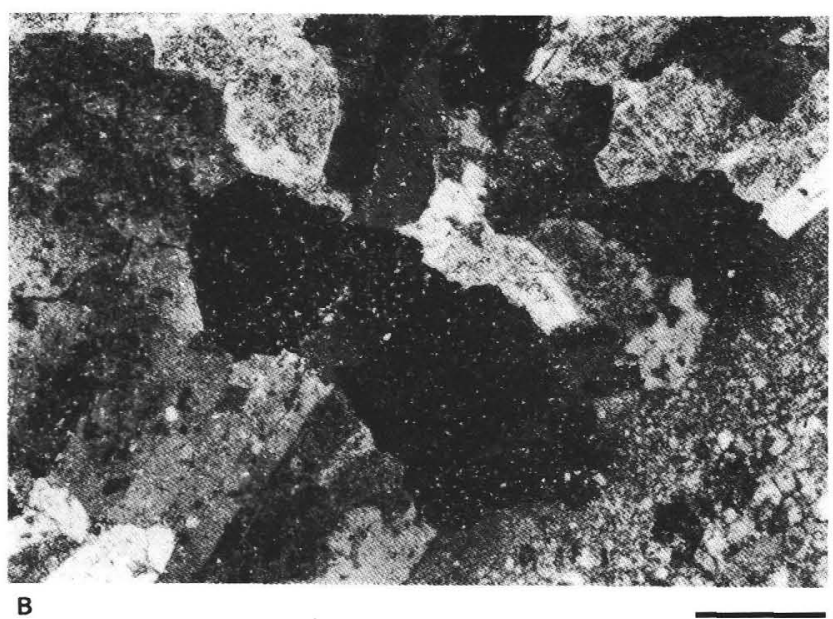

Figure 8. Dolomite filling narrow fracture to form a clear vein (Sample 103-639A-10R-1, 105-108 cm). Scale bar represents $0.25 \mathrm{~mm}$. A. Transmitted light. B. The optical continuity of the host is preserved across clear vein. Crossed nicols.

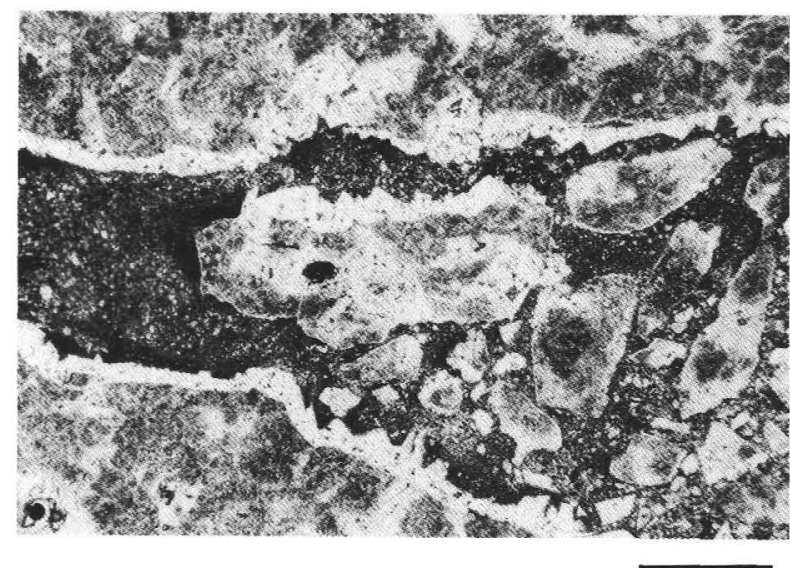

Figure 9. Crystals with curved crystal boundaries lining the wider fractures (Sample 103-639A-10R-1, 105-108 cm). Scale bar represents $1 \mathrm{~mm}$. Transmitted light. and opened by a later fracturing event. Some wide fractures are distinctly lined by chevron-shaped baroque crystals (Fig. 10).

The relative timing of the fracturing of the host rock is documented in Sample 103-639A-10R-1, 105-108 cm. The host adjacent to the infilled fractures (clear veins) and the clear dolomite crystals are similar petrographically because they are in optical continuity (see Figs. 8A and 8B). This indicates that fracturing occurred after dolomitization of the host and that the clear crystals lining the fractures nucleated on the host, with which they are now in optical continuity. However, neomorphism could be responsible for the optical continuity of the host and the crystals lining the fractures.

Fragments of the clear dolomite crystals and large clasts of the host dolomite are found in the internal sediment. These large clasts of the host dolomite are rimmed on one side by the clear crystals (see Fig. 9), indicating that the clasts were eroded from the fracture walls after the clear dolomite formed. Therefore, fractures filled with internal sediment are interpreted to postdate the crystallization of the clear dolomite.

The impurities present in the anhedral crystals forming the host and in the cores of the rhombohedral dolomite appear petrographically as diffuse, light brown inclusions and dark brown or black inclusions. The diffuse, light brown inclusions are most common, and they appear white or yellow under reflected light. The crystals with these diffuse inclusions are petrographically similar to the turbid nature of echinoderm fragments that develops because of the intraskeletal microporosity.

The core areas of the dolomite crystals rich in impurities were also examined with the SEM. Rectangular voids with sharp edges are pervasive in the core areas of the dolomite in Sample 103-639A-10R-2, 16-19 cm (Figs. 11A and 11B). The voids are interpreted to be negative crystals formed during growth. The similarity of the turbid core areas to echinoderm fragments is interpreted as resulting from micropores within the crystal.

Evidence for dolomite dissolution is present in Unit IV. Core areas of rhombohedral dolomite crystals are either partially (Fig. 12A) or totally absent (Fig. 12B), leaving a well-developed rim. These features are present in Samples 103-639A-9R-1, 4$9 \mathrm{~cm}$, and 103-639C-2R-2, 89-92 cm. Detailed examination of Sample 103-639C-2R-2, 89-92 cm, found the edges of the remaining rims and cores to be irregular, suggesting dissolution (Fig. 13). The dissolution indicates that the initial composition of the cores was less stable or became less stable through diagenesis in comparison to the rims, and dissolution occurred.

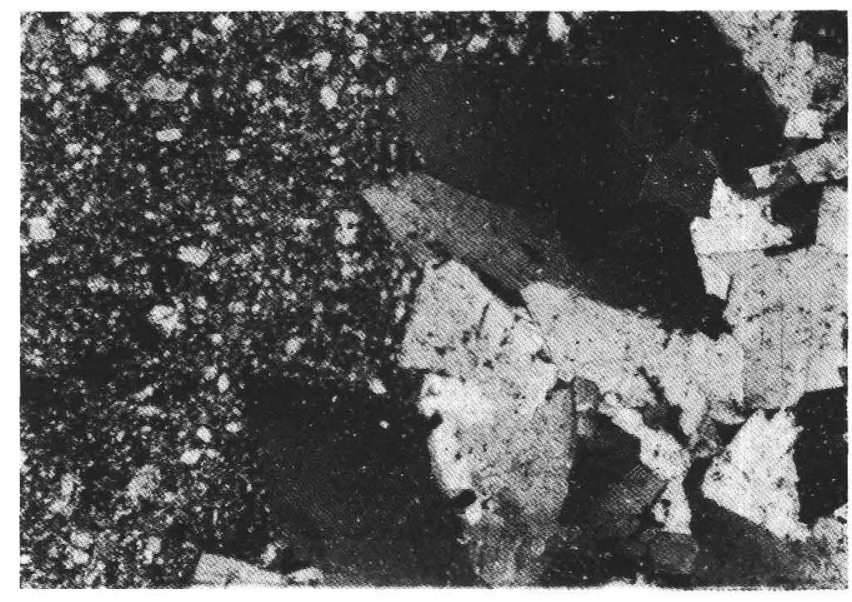

Figure 10. Chevron-shaped baroque crystals lining wide fractures (Sample 103-639A-8R, CC [6-11 cm]). Scale bar represents $0.25 \mathrm{~mm}$. Crossed nicols. 


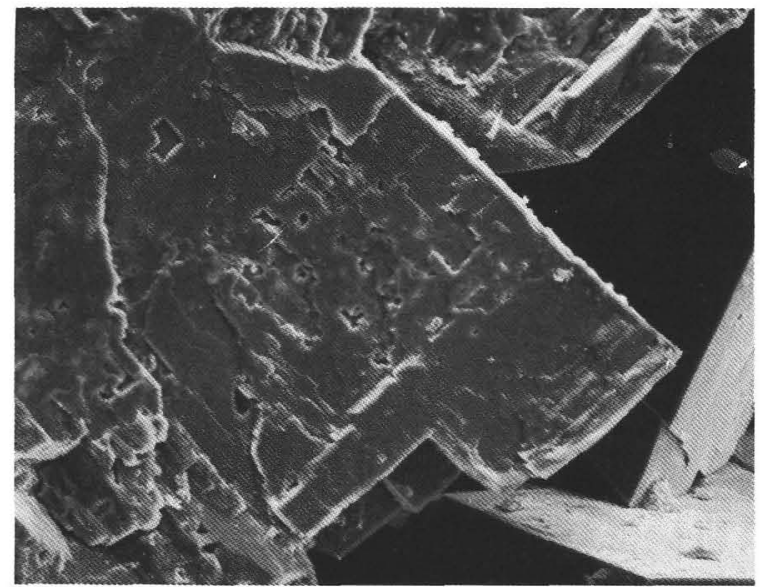

A

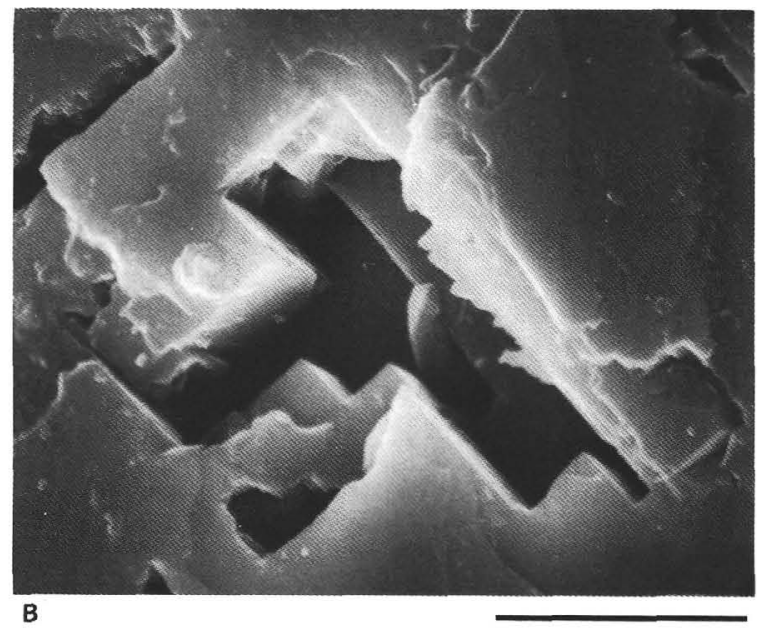

Figure 11. Pervasive rectangular voids in the core areas of dolomite crystals (Sample 103-639A-10R-2, 16-19 cm). SEM. A. Scale bar represents $0.2 \mathrm{~mm}$. B. Close-up of Figure 11A, showing the rectangular voids with sharp edges. Scale bar represents $0.01 \mathrm{~mm}$.

\section{Unit $V$}

Although Unit V is dominantly limestone, the strata are partially dolomitized. Rhombohedra or irregular patches of dolomite are present, and dolomite veins are common throughout the unit. The isolated rhombohedra and large patches of dolomite are associated with stylolites in both the oncolitic and skeletal facies of the unit.

The upper strata consisting of skeletal wackestone contain irregular patches of clear, baroque dolomite (Figs. 14A and 14B) and porphyrotopic (Friedman, 1965) calcite (Fig. 15). The dolomite crystals are dominantly anhedral, although they may exhibit well-developed chevrons. The association of patches of dolomite and calcite with low-amplitude stylolites produces a brecciated appearance. The clear dolomite in some areas surrounds porphyrotopic calcite (see Fig. 15).

Stylolitization is pervasive within the muddy matrix, and the stylolites commonly enclose dolomite rhombohedra (Fig. 16), although they are also present in the absence of dolomite. These dolomite rhombohedra are present only in association with the stylolitic seams and are not disseminated throughout the micritic matrix. Stylolites also rim the clear dolomite patches (see Figs. 14A and 14B). Thus, stylolites are strongly associated with the occurrence of dolomite and are interpreted to be a factor in the dolomitization of the strata. Stylolites may serve as an ave-

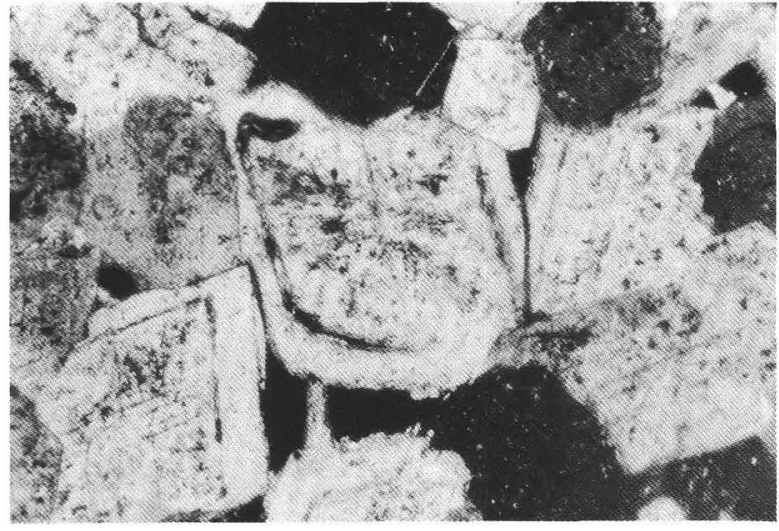

A

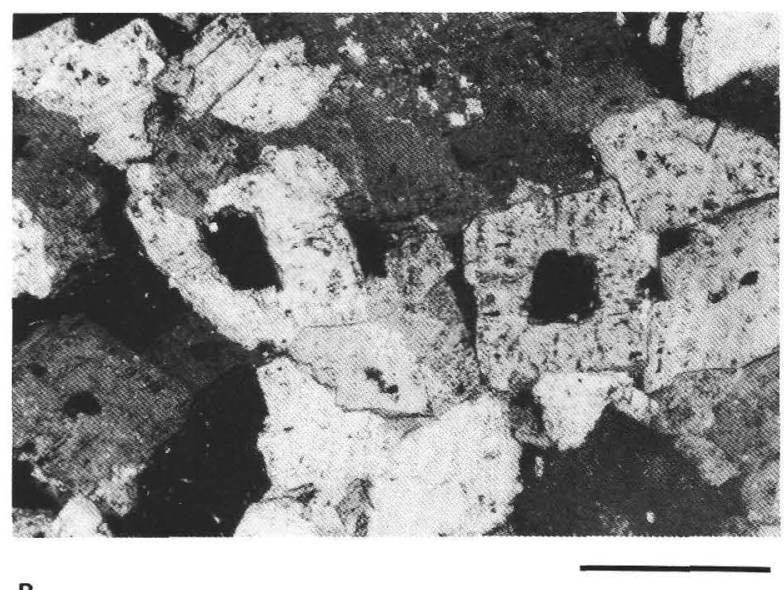

B

Figure 12. A. Dolomite with partially absent core areas (Sample 103$639 \mathrm{C}-2 \mathrm{R}-2,89-92 \mathrm{~cm}$ ). Scale bar represents $0.25 \mathrm{~mm}$. Crossed nicols. B. Dolomite without core areas (Sample 103-639A-9R-1, 4-9 cm). Scale bar represents $0.25 \mathrm{~mm}$. Crossed nicols.

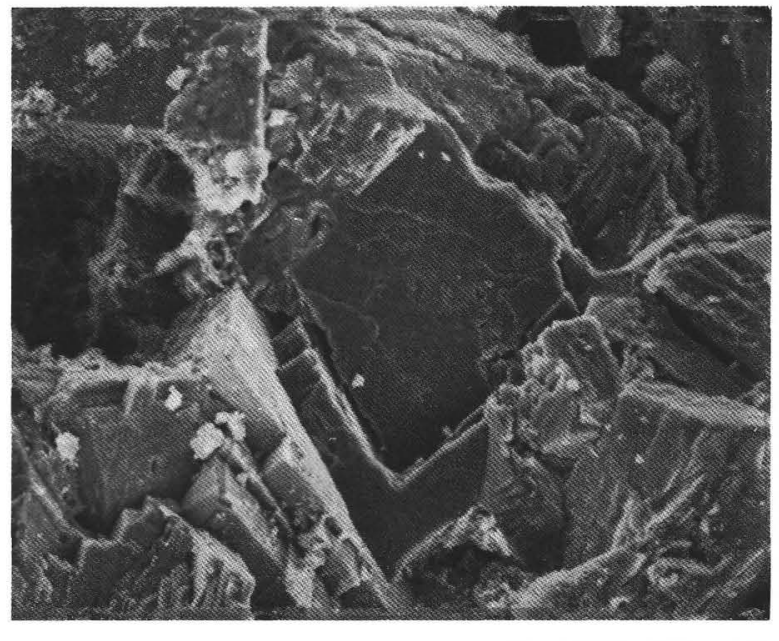

Figure 13. Irregular edges of dolomite rims and remaining core areas (Sample 103-639C-2R-2, 89-92 cm). Scale bar represents 0.2 mm. SEM. 


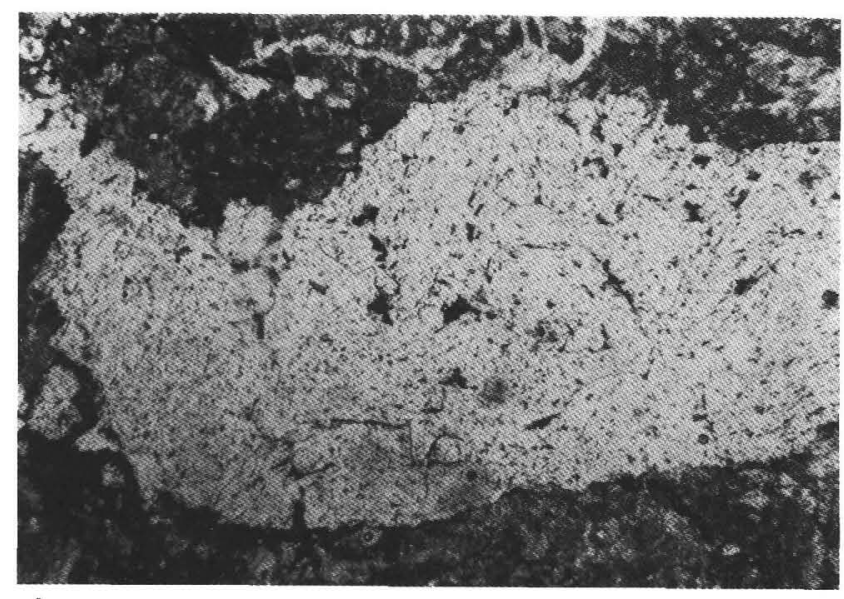

A

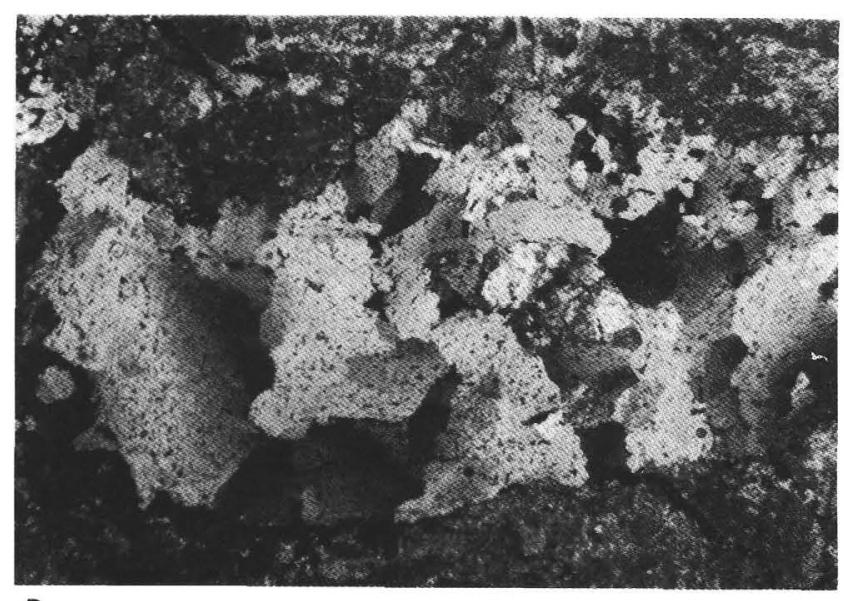

B

Figure 14. Patches of clear, baroque dolomite (Sample 103-639D-5R-2, 124-128 cm). Scale bar represents $1 \mathrm{~mm}$. A. Transmitted light. B. Crossed nicols.

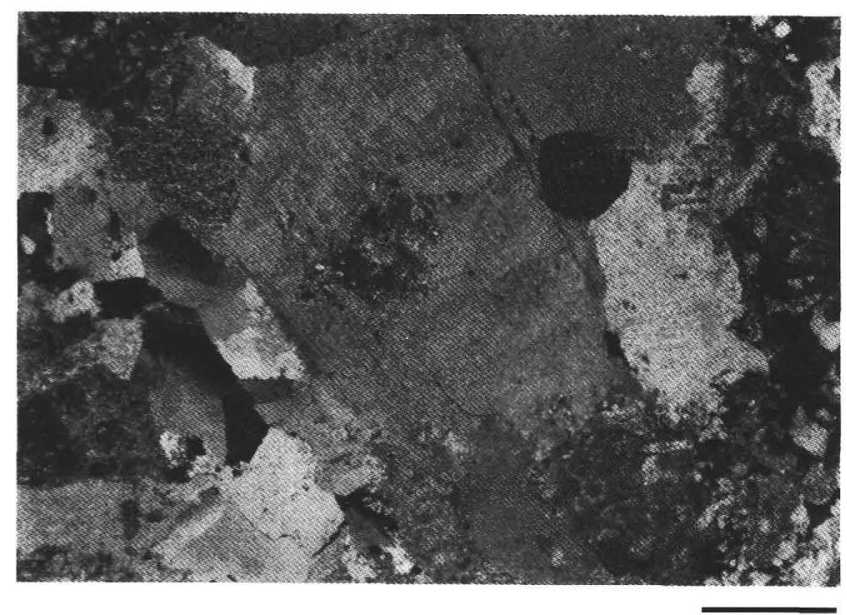

Figure 15. Porphyrotopic calcite (Sample 103-639D-5R-2, 124-128 cm). Scale bar represents $1 \mathrm{~mm}$. Crossed nicols.

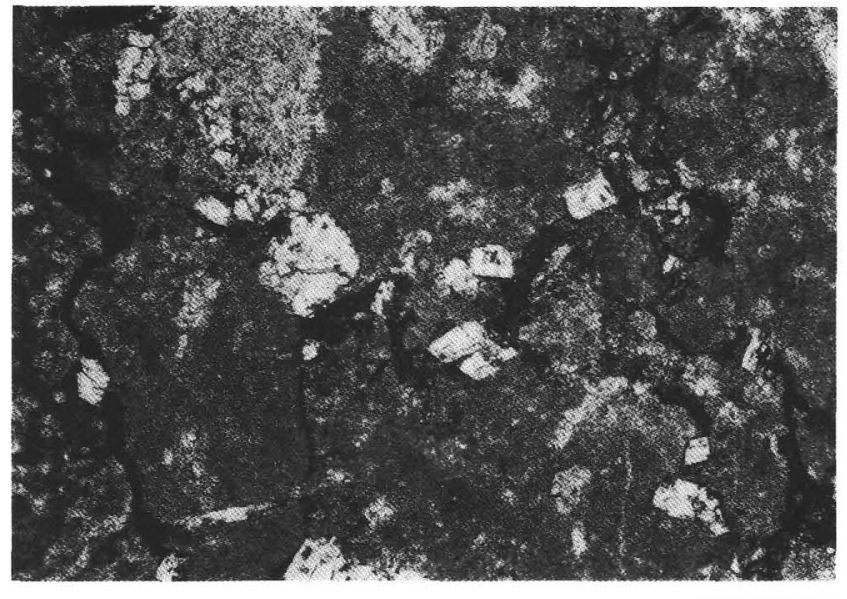

Figure 16. Dolomite rhombohedra enclosed by stylolites (Sample 103639D-5R-2, 124-128 cm). Scale bar represents $0.25 \mathrm{~mm}$. Transmitted light.

nue for ion transport parallel to the seam, and may develop a high concentration of magnesium (Wanless, 1979). Thus, microenvironments conducive to dolomite formation could have developed in or nearby the stylolitic seams. Therefore, the dolomite rhombohedra are interpreted to have formed in association with the stylolitization of the limestone, rather than being concentrated solely by subsequent pressure solution of the matrix.

\section{Geochemistry}

Variations in the geochemistry of the dolomite are documented with cathodoluminescence and electron microprobe analysis. Overall, the host dolomite luminesces orange or red orange. Cathodoluminescent cement stratigraphy is documented from the dolomite lining fractures and as isolated rhombohedra in Unit IV and from the dolomite patches in Unit V. In both units, the luminescent bands are within crystal boundaries observed in transmitted light, indicating subsequent aggrading neomorphism has not occurred.

\section{Unit IV}

The clear dolomite lining the wide fractures of Samples 103639A-8R, CC (6-11 cm), and 103-639A-10R-1, 105-108 cm, exhibits four luminescent zones (Figs. 17A and 17B), regardless of the crystal morphology. A yellow luminescence is observed from zone 1 , and the boundary between it and the host is indistinct. This zone probably represents the chemistry of the host as well. A similar yellow luminescence was observed from detrital fragments of the host dolomite caught in the internal sediment filling the fractures. The proximal zone within the crystals (zone 2) luminesces orange. The clear detrital dolomite exhibits a similar luminescence. An olive green luminescence is observed from zone 3. The outer edge of the crystals (zone 4 ) does not luminesce. This narrow dark rim is also present on some of the detrital dolomite in the internal sediment filling the fractures.

The electron microprobe was used to analyze the geochemical variations of the luminescence zones on a traverse of 100 analytical points across a baroque crystal in Sample 103-639A$8 \mathrm{R}, \mathrm{CC}(6-11 \mathrm{~cm})$ (Fig. 17B). The analyses of all the points from each zone were averaged to determine the elemental concentrations associated with each zone and are presented in Table 1. Sodium, sulfur, and strontium are extremely variable on the scale of these observations (Figs. 18A through 18C). Iron and magnesium display a more systematic trend (Figs. 18D and 18E). 

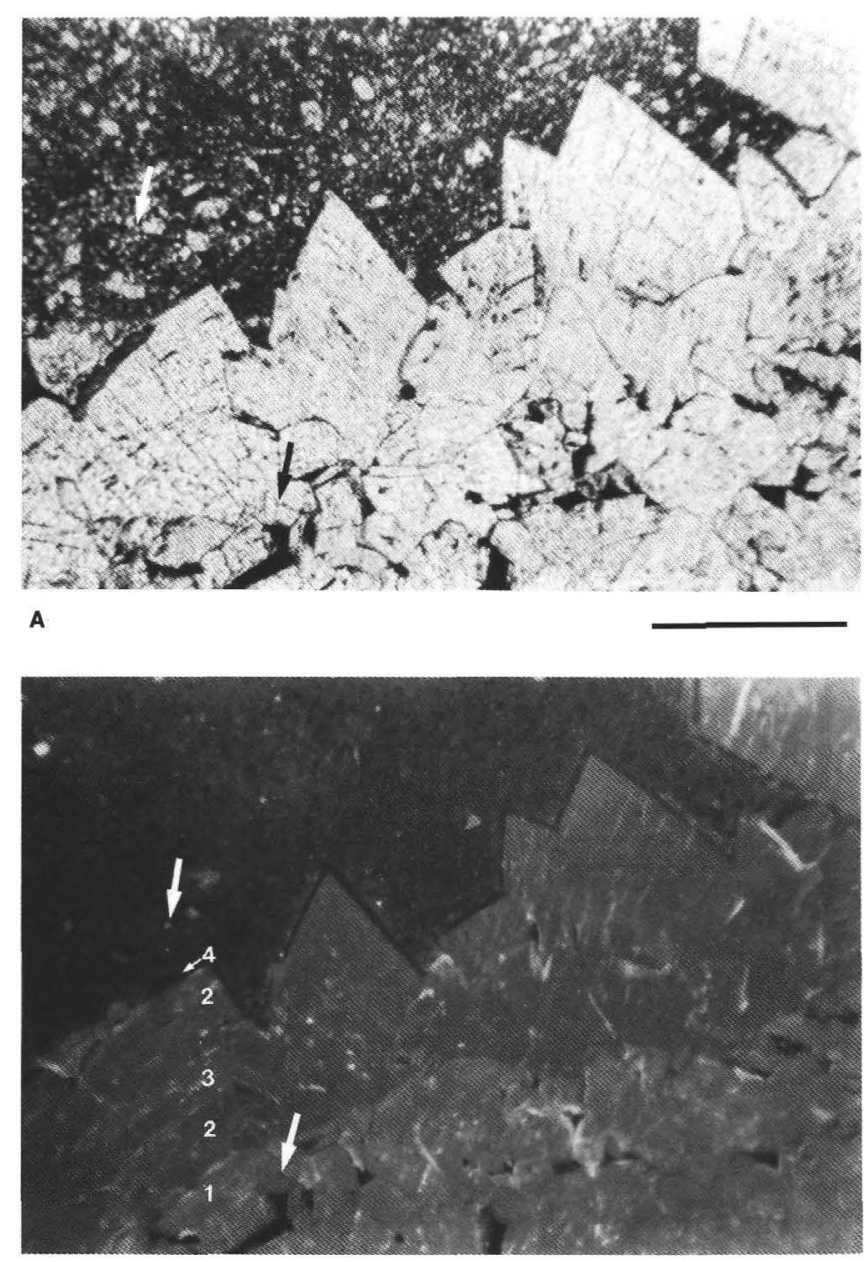

B

Figure 17. Clear, baroque dolomite lining wide fracture (Sample 103$639 \mathrm{~A}-8 \mathrm{R}, \mathrm{CC}[6-11 \mathrm{~cm}])$. Arrows indicate the beginning and end of the transect analyzed with the electron microprobe. Scale bar represents $0.5 \mathrm{~mm}$. A. Transmitted light. B. Luminescent zones exhibited by baroque dolomite. The numbers correspond to the zonation discussed in the text and used in Figure 18 and Table 1. Cathodoluminescence.

The difference in the luminescence of the yellow (zone 1) and orange (zone 2) areas may be attributed to different concentrations of iron and magnesium. The olive green zone (3) is characterized by the highest iron and high magnesium concentrations, whereas zone 4 is characterized by relatively high iron and high- est magnesium contents. The relatively high average concentration of sodium and the relatively low strontium and magnesium concentrations (see Table 1) in the olive green zone may explain why this luminescence occurs in spite of the higher iron content. Manganese did not show any systematic trend in the crystal. The average concentration of manganese in each zone is very low (Table 1) fluctuating near and below the detection limit of $80 \mathrm{ppm}$.

Rhombohedra in the lower strata of Unit IV (Sample 103639D-2R, CC [5-7 cm]) are characterized by turbid cores and clear rims (Fig. 19A). Under cathodoluminescence the clear rims exhibit cement stratigraphy characterized by six distinct alternating bands of yellow, orange, and dark luminescence (Fig. 19B). The chemistry of these bands was determined by electron microprobe analysis of 100 transect points across a rhombohedron; therefore, the traverse crossed each luminescent band twice. The variation in composition is shown in Figure 20, and the analyses of all points from each zone were averaged to determine elemental concentrations in each band and are presented in Table 2.

Sodium, sulfur, and strontium are variable on the scale of these observations (Figs. 20A through 20C). Magnesium concentration fluctuates throughout the crystal with no distinct trend (Fig. 20D). The manganese and iron concentrations display a more systematic trend in this rhombic crystal (Figs. 20E and $20 \mathrm{~F}$ ).

High iron contents distinguish the dark bands (zones 1 and 3 ) along the outer edge of the clear rim. These bands are separated from each other and from zone 5 by narrow yellow bands (zones 2 and 4). Zone 3 contains the relatively highest average iron content; zone 1 contains relatively less iron. The two narrow yellow bands adjacent to the dark bands contain less iron than the dark bands. Zone 2 averages $1200 \mathrm{ppm} \mathrm{Fe}$, and zone 4 averages $300 \mathrm{ppm} \mathrm{Fe}$. The iron contents of both the yellow and dark bands decrease with their proximity to the turbid core. The average manganese contents of zones 1 and 3 are also relatively high. The remainder of the clear rim is formed of two luminescent bands, zones 5 and 6 . These bands are characterized by lower iron and manganese contents than in zones 1 through 4 (Fig. 20 and Table 2).

The turbid core is characterized by variable elemental concentrations. Both the turbid nature of the core and the variable values may be the result of microinclusions within the crystal.

\section{Unit $V$}

Cement stratigraphy was also observed in a patch of dolomite from the upper strata of Unit V in Sample 103-639D-5R-2, $124-128 \mathrm{~cm}$. Cathodoluminescence provided evidence for geochemical variations and delineated chevron-shaped and rhom-

Table 1. Average elemental concentrations of cathodoluminescent zones in baroque dolomite from Sample 103-639A-8R, CC (6-11 cm) (Unit IV). Values in parentheses are one standard deviation of the average. Zone numbers correspond to regions of cement stratigraphy labeled in Figure 17B.

\begin{tabular}{|c|c|c|c|c|c|c|c|}
\hline Zone & $\begin{array}{c}\mathrm{Ca} \\
(\mathrm{ppm})\end{array}$ & $\underset{(\mathrm{ppm})}{\mathrm{Mg}}$ & $\begin{array}{c}\mathrm{Sr} \\
(\mathrm{ppm})\end{array}$ & $\underset{(\mathrm{ppm})}{\mathrm{Mn}}$ & $\underset{(\mathrm{ppm})}{\mathrm{Fe}}$ & $\begin{array}{c}\mathrm{Na} \\
(\mathrm{ppm})\end{array}$ & $\underset{(\mathrm{ppm})}{\mathrm{S}}$ \\
\hline 1 (yellow) & $\begin{array}{c}257500 \\
( \pm 6800)\end{array}$ & $\begin{array}{c}107600 \\
( \pm 5000)\end{array}$ & $\begin{array}{c}400 \\
( \pm 100)\end{array}$ & $\begin{array}{r}60 \\
( \pm 20)\end{array}$ & $\begin{array}{r}80 \\
( \pm 60)\end{array}$ & $\begin{array}{r}200 \\
( \pm 100)\end{array}$ & $\begin{array}{r}300 \\
( \pm 100)\end{array}$ \\
\hline 2 (orange) & $\begin{array}{c}256800 \\
( \pm 14200)\end{array}$ & $\begin{array}{l}116000 \\
( \pm 500)\end{array}$ & $\begin{array}{r}400 \\
( \pm 200)\end{array}$ & $\begin{array}{r}40 \\
( \pm 30)\end{array}$ & $\begin{array}{r}200 \\
( \pm 400)\end{array}$ & $\begin{array}{r}100 \\
( \pm 200)\end{array}$ & $\begin{array}{r}200 \\
( \pm 100)\end{array}$ \\
\hline 3 (olive green) & $\begin{array}{c}251100 \\
( \pm 7100)\end{array}$ & $\begin{array}{c}112500 \\
( \pm 3000)\end{array}$ & $\begin{array}{c}400 \\
( \pm 100)\end{array}$ & B.D. & $\begin{array}{r}4800 \\
( \pm 3000)\end{array}$ & $\begin{array}{r}500 \\
( \pm 300)\end{array}$ & $\begin{array}{r}200 \\
( \pm 50)\end{array}$ \\
\hline 4 (dark) & $\begin{array}{c}194200 \\
( \pm 12200)\end{array}$ & $\begin{array}{c}117900 \\
( \pm 1100)\end{array}$ & $\begin{array}{c}600 \\
( \pm 300)\end{array}$ & $\begin{array}{r}40 \\
( \pm 30)\end{array}$ & $\begin{array}{c}1100 \\
( \pm 1800)\end{array}$ & $\begin{array}{c}200 \\
( \pm 100)\end{array}$ & $\begin{array}{r}200 \\
( \pm 100)\end{array}$ \\
\hline
\end{tabular}

Note: B.D. = all values below detection limit for the element. 

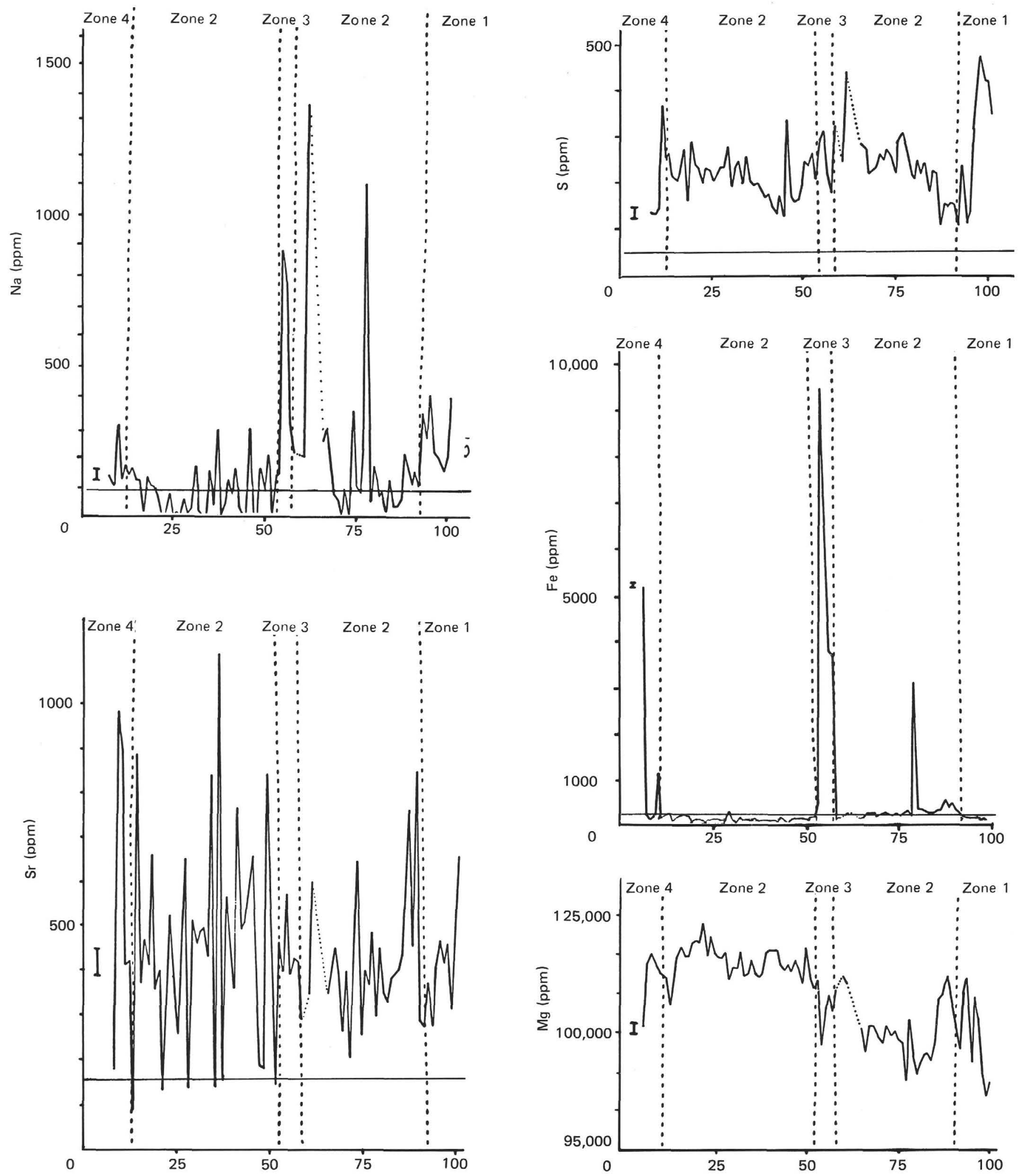

Figure 18. Concentrations at 91 locations across baroque dolomite (Sample 103-639A-8R, CC [6-11 cm]). The concentrations are extremely variable on the scale of the observations. Microprobe detection limit is represented by a thick horizontal line through the data. The standard deviation of each analysis is represented by the error bar on the left of the figure. A. Sodium concentrations. Microprobe detection limit $=90 \mathrm{ppm}$; standard deviation $=35 \mathrm{ppm}$. B. Sulfur concentrations. Microprobe detection limit $=30 \mathrm{ppm}$; standard deviation $=20 \mathrm{ppm}$. C. Strontium concentrations. Microprobe detection limit $=160 \mathrm{ppm}$; standard deviation $=100 \mathrm{ppm}$. D. Iron concentrations. Microprobe detection limit $=30 \mathrm{ppm} ; \mathrm{standard}$ deviation $=20$ ppm. E. Magnesium concentrations. Microprobe detection limit $=370 \mathrm{ppm}$ (not within the scale of this graph); standard deviation $=1110 \mathrm{ppm}$. 

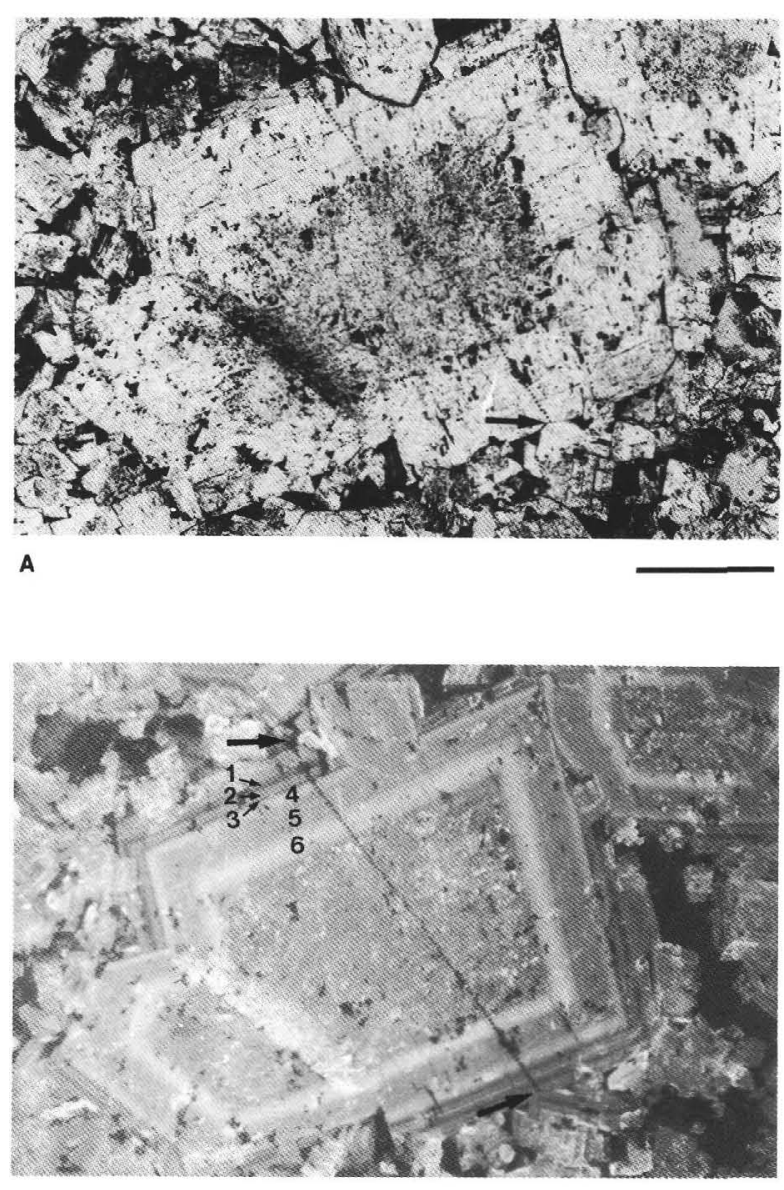

B

Figure 19. Rhombohedral dolomite with turbid core (Sample 103-639D$2 \mathrm{R}, \mathrm{CC}[5-7 \mathrm{~cm}])$. Arrows indicate the beginning and end of the transect analyzed with the electron microprobe. Scale bar represents 0.25 mm. A. Transmitted light. B. Luminescent zones exhibited by dolomite rhombohedra. The numbers correspond to the zonation discussed in the text and used in Figure 20 and Table 2. Cathodoluminescence.

bohedral crystals within the patch that had not been previously identified using standard petrographic techniques (Fig. 21A). The center of the vein exhibits dark luminescence. Other crystals that form the vein exhibit several luminescent zones (Fig. 21B). These zones alternate from red orange luminescence to dark luminescence.

To quantify the chemistry of the zones, electron microprobe analysis was conducted on selected points through one of the crystals in Sample 103-639D-5R-2, 124-128 cm, in which a yellow luminescent band (zone 2) is surrounded by two dark nonluminescent bands (zones 1 and 3; Fig. 21B) and the central area is dark (zone 4). Averaged elemental concentrations are presented in Table 3.

General trends in Table 3 include an increase in iron content coupled with a decrease in sulfur and usually with an increase in manganese. All of the average sodium concentrations fall below the $300-\mathrm{ppm}$ detection limit for this element. The average iron content of zone 4 is nearly double that of zone 3 . The vivid yellow band (zone 2 ) is characterized by a low iron content, strong depletion of magnesium, and an increase in calcium. The elemental concentrations in zone 2 are consistent with a calcite composition.

The increase in manganese toward the center of the patch indicates an enrichment of this element during growth. The iron concentration is relatively low in zone 2 (Table 3 ). Although the dark band (zone 3 ) has a higher average manganese content, the significantly higher average iron concentration may account for the absence of the typical yellow or orange luminescence of manganese (Pierson, 1981), such as in zone 2.

Selected points in the porphyrotopic calcite and the calcite matrix were also analyzed, and the average elemental concentrations are presented in Table 4. The average sulfur content of the porphyrotopic calcite (70 ppm S) is the most significant difference in comparison to the matrix $(300 \mathrm{ppm} \mathrm{S})$ of the average elemental concentrations.

\section{DISCUSSION}

\section{Depositional Environments}

The depositional environments of the units forming the tilted block indicate an increase in water depth with progressively younger strata. Unit $\mathrm{V}$ is significant as it was retrieved from a single hole (639D) and thus, is the most accurate representation of the stratigraphic sequence obtained at this site. Although Unit IV stratigraphically overlies the strata recovered at Hole 639D, the contact between the units was not recovered. Additional faulting within the horst may mask the true stratigraphic relationship of the strata within Unit IV and its relationship to Unit V.

The fossils associated with Unit IV indicate deposition in a shelf environment, and thus, the depositional environment of this strata does not appear to differ significantly from Unit V. The depositional environment of the overlying syn-rift sediments (Unit III) indicates an abrupt increase in water depth, although the contact between Units III and IV was not recovered.

\section{Diagenesis}

Unit $\mathrm{V}$ is partially dolomitized, and its diagenesis may be related to that of Unit IV, which includes dolomitization, fracturing, vug formation, vug and fracture filling, and dissolution. Although the relative timing of these events may be inferred, subsequent recrystallization processes could have overprinted some textural evidence.

The dolomitization of Unit IV is pervasive throughout the unit as crystals forming the host, lining the vugs and fractures, and forming the clear veins are dolomite. The morphology of the dolomite crystals varies from anhedral and rhombohedral host crystals to rectangular and chevron-shaped clear crystals that line the vugs and fractures and form the veins. Geochemical variations are documented between the host and the clear crystals and within the individual crystals.

Cathodoluminescence petrography shows cement stratigraphy patterns that indicate the relative timing and homogeneity of geochemical variations. Geochemical variations that occurred during dolomitization were homogeneous in similar features throughout the unit; similar cement stratigraphy patterns were observed from the clear dolomite lining the wide fractures in Samples 103-639A-8R, CC (6-11 cm), and 103-639A-10R-1, 105$108 \mathrm{~cm}$. In these samples, the following features are significant: (1) a continuation of yellow luminescence from the host into the area of the clear crystals immediately adjacent to the host (zone 1 in Sample 103-639A-8R, CC [6-11 cm]), (2) a fairly uniform orange luminescence throughout the majority of the crystals (zone 2 in Sample 103-639A-8R, CC [6-11 cm]), and (3) a narrow dark band at the outer edge of the crystals (zone 4 in Sample 103-639A-8R, CC [6-11 cm]).

Cathodoluminescence results also indicate a significant difference between the clear dolomite lining the wide fractures and that forming the veins; the clear veins are indistinct from the host in that the orange and dark luminescent areas are not present 

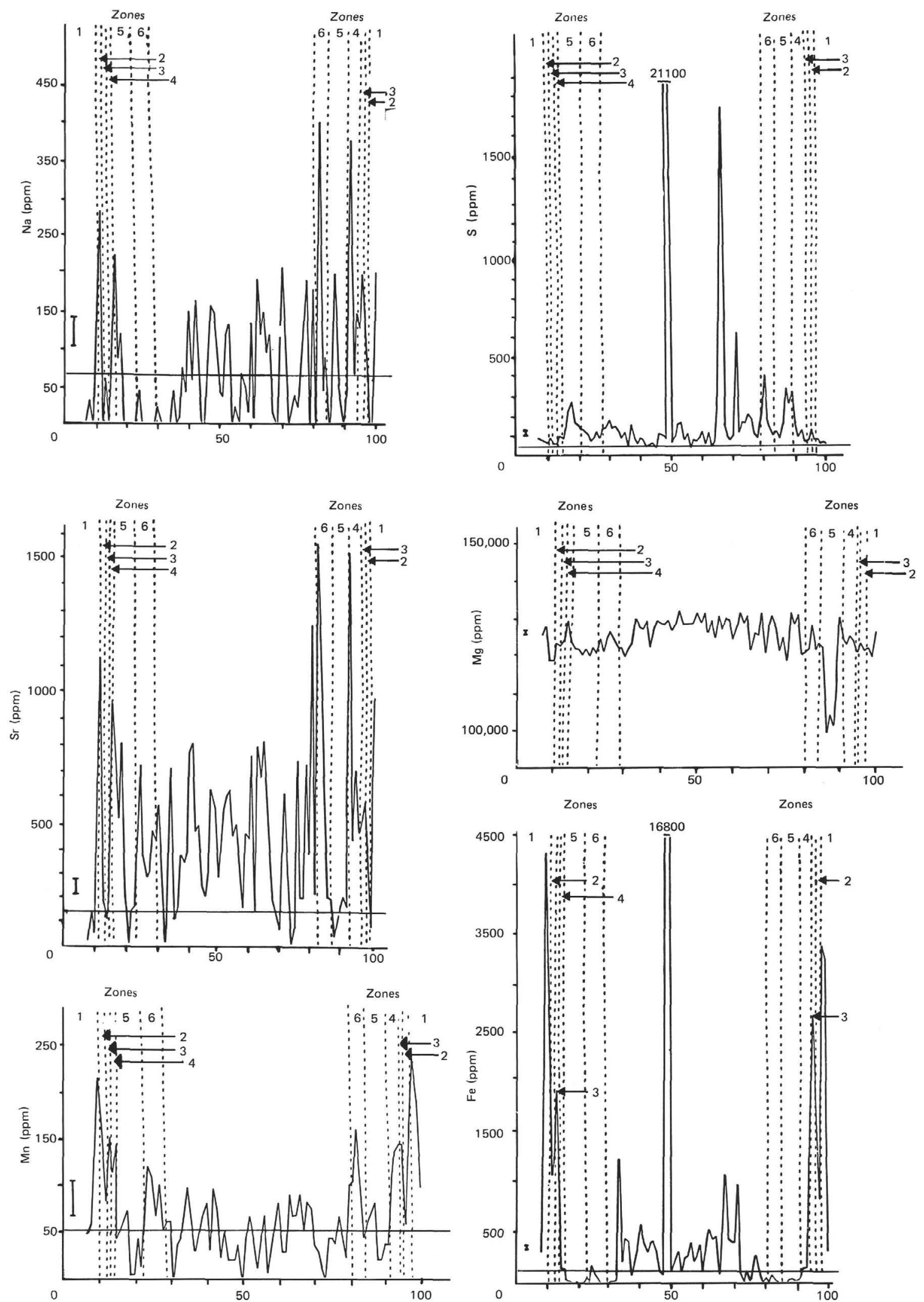

Figure 20. Concentrations at 93 locations across rhombohedral dolomite from Sample 103-639D-2R, CC (5-7 cm). The concentrations are extremely variable on the scale of the observations. Microprobe detection limit is represented by a thick horizontal line through the data. Standard deviation of each analysis is represented by the error bar on the left of the figures. A. Sodium concentrations. Microprobe detection limit = $70 \mathrm{ppm}$; standard deviation $=45 \mathrm{ppm}$. B. Sulfur concentrations. Microprobe detection limit $=30 \mathrm{ppm}$; standard deviation $=20 \mathrm{ppm}$. C. Strontium concentrations. Microprobe detection limit $=140 \mathrm{ppm}$; standard deviation $=80 \mathrm{ppm}$. D. Magnesium concentrations. Microprobe detection limit $=340 \mathrm{ppm}($ not within the scale of this graph); standard deviation $=1120 \mathrm{ppm}$. E. Manganese concentrations. Microprobe detection limit $=60 \mathrm{ppm}$; standard deviation $=40 \mathrm{ppm}$. F. Iron concentrations. Microprobe detection limit $=50 \mathrm{ppm}$; standard deviation $=30 \mathrm{ppm}$. 
Table 2. Average elemental concentrations of cathodoluminescent zones in rhombohedral dolomite from Sample 103-639D-2R, CC (5-7 cm) (Unit IV). Values in parentheses are one standard deviation of the average. Zone numbers correspond to regions of cement stratigraphy labeled in Figure 19B.

\begin{tabular}{lccccccc}
\hline Zone & $\begin{array}{c}\mathrm{Ca} \\
(\mathrm{ppm})\end{array}$ & $\begin{array}{c}\mathrm{Mg} \\
(\mathrm{ppm})\end{array}$ & $\begin{array}{c}\mathrm{Sr} \\
(\mathrm{ppm})\end{array}$ & $\begin{array}{c}\mathrm{Mn} \\
(\mathrm{ppm})\end{array}$ & $\begin{array}{c}\mathrm{Fe} \\
(\mathrm{ppm})\end{array}$ & $\begin{array}{c}\mathrm{Na} \\
(\mathrm{ppm})\end{array}$ & $\begin{array}{c}\mathrm{S} \\
(\mathrm{ppm})\end{array}$ \\
\hline 1 (dark) & 230400 & 123200 & 300 & 200 & 2100 & 50 & 100 \\
& $( \pm 7200)$ & $( \pm 3500)$ & $( \pm 300)$ & $( \pm 70)$ & $( \pm 1600)$ & $( \pm 70)$ & $( \pm 10)$ \\
2 (yellow) & 233400 & 123200 & 600 & 100 & 1200 & 200 & 100 \\
& $( \pm 4100)$ & $( \pm 700)$ & $( \pm 300)$ & $( \pm 50)$ & $( \pm 300)$ & $( \pm 100)$ & $( \pm 100)$ \\
3 (dark) & 233300 & 122700 & 300 & 150 & 2300 & 90 & 100 \\
& $( \pm 4700)$ & $( \pm 1600)$ & $( \pm 200)$ & $( \pm 400)$ & $( \pm 30)$ & $( \pm 30)$ & $( \pm 30)$ \\
4 (yellow) & 235900 & 125500 & 800 & 100 & 300 & 100 & 100 \\
& $( \pm 4700)$ & $( \pm 2100)$ & $( \pm 500)$ & $( \pm 20)$ & $( \pm 400)$ & $( \pm 100)$ & $( \pm 20)$ \\
5 (orange) & 235000 & 132300 & 600 & 40 & 20 & 60 & 200 \\
6 (yellow) & $( \pm 6800)$ & $( \pm 9200)$ & $( \pm 200)$ & $( \pm 30)$ & $( \pm 20)$ & $( \pm 70)$ & $( \pm 100)$ \\
& $( \pm 6400)$ & $( \pm 32600$ & 600 & 100 & 40 & 60 & 100 \\
& $( \pm 3000)$ & $( \pm 400)$ & $( \pm 40)$ & $( \pm 50)$ & $( \pm 100)$ & $( \pm 20)$ \\
\hline
\end{tabular}

Note: B.D. = all values below detection limit for the element.
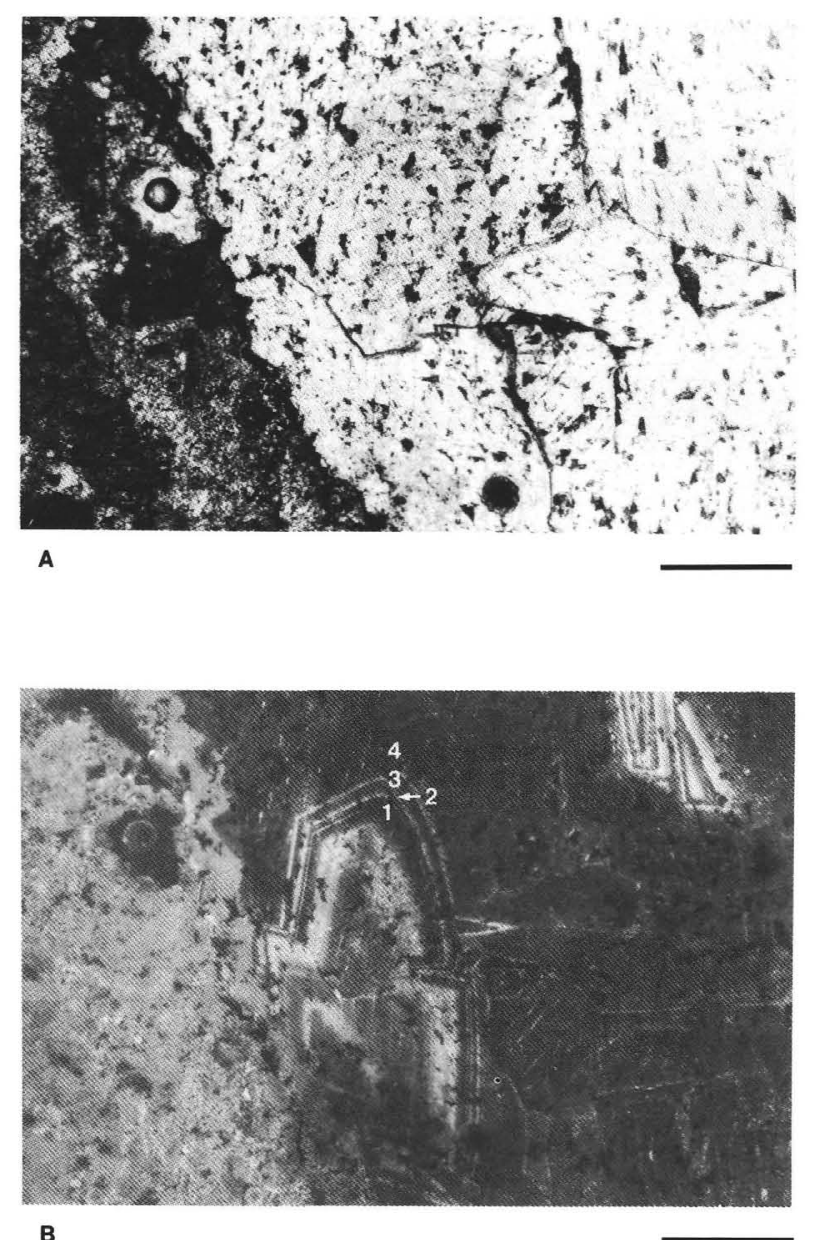

Figure 21. Patch of dolomite within the upper strata of Unit V (Sample 103-639D-5R-2, 124-128 cm). Scale bar represents $0.25 \mathrm{~mm}$. A. Transmitted light. B. Luminescent zones exhibited by crystal in patch of dolomite. The numbers correspond to the zonation discussed in the text and Table 3. Cathodoluminescence.

within them. This observation indicates that the clear veins were impermeable to the dolomitization fluids that produced the orange and dark luminescent zones in the clear crystals lining the wider fractures. This impermeability, in addition to the similar morphologies of the crystals in clear veins and wide fractures, indicates that the wide fractures initially formed as clear veins and were subsequently opened by a later fracturing event. This opening allowed later dolomitizing fluids to reach the clear crystals.

Elemental analyses are used as a means of determining chemical variations in the dolomitizing fluids and thus, the diagenetic environment. A comparison of elemental averages in the luminescent zones of a single dolomite crystal should reflect the change in the quantity of the element present at a site during diagenesis. However, other possible controls on elemental composition should be taken into account: (1) the concentration of solid and fluid inclusions that may be incorporated into the crystal lattice (Hardie, 1987), (2) the concentration of the elements in the precursor mineral (Mattes and Mountjoy, 1980), (3) the rate of ion diffusion across an intercrystalline diffusion gradient (Mattes and Mountjoy, 1980), (4) the rate of crystallization, and (5) subsequent dolomitization and neomorphic replacement of previously formed dolomite (Land, 1980).

The geochemical profiles presented in Figures 18 and 20 show that the distribution of sodium, strontium, and sulfur in dolomite is extremely variable. Two adjacent points within a $3-\mu \mathrm{m}$ span show the complete compositional range of these elements. The nonsystematic variation of these elements suggests that they mainly occur as inclusions, rather than ionic substitutions, in the crystal structure.

In the transect of the baroque dolomite (Fig. 18 and Table 1) as well as in the transect of the rhombic dolomite (Fig. 20 and Table 2), the strontium ranges from near the detection limits (140 ppm) to $1500 \mathrm{ppm}$. Bein and Land (1983) attribute strontium in excess of $200 \mathrm{ppm}$ in Permian San Andres dolomite to ultramicroscopic celestite inclusions. Macroscopic celestite beds are known to occur in their study area. Celestite inclusions in other dolomites have been petrographically observed by Friedman and Radke (1979). Celestite has also been found in association with penecontemporaneous dolomite in the Persian Gulf (Illing et al., 1965) and the Coorong, Australia (Skinner, 1963). These celestite associations all occur in hypersaline dolomites.

Other Leg 103 studies of the geochemistry of dolomite (Haggerty and Smith, this volume) and of the interstitial water (Haggerty and Fisher, this volume) indicate an association of evaporitic minerals with the dolomite. Haggerty and Smith (this volume) conducted dolomite pyrolysis mass spectrometry. This technique indicates the presence of microinclusions of strontium sulfate, calcium sulfate, and sodium-magnesium sulfate minerals, which suggests that dolomitization resulted from hypersaline brines. The variable sodium contents determined by microprobe analyses of the baroque dolomite and the rhombohedral dolomite could be the result of halite or sodium sulfate inclusions. 
Table 3. Average elemental concentrations of cathodoluminescent zones in dolomite from Sample 103-639D-5R-2, 124-128 cm (Unit V). Values in parentheses are one standard deviation of the average. Zone numbers correspond to regions of cement stratigraphy labeled in Figure 21B.

\begin{tabular}{cccccccc}
\hline Zone & $\begin{array}{c}\mathrm{Ca} \\
(\mathrm{ppm})\end{array}$ & $\begin{array}{c}\mathrm{Mg} \\
(\mathrm{ppm})\end{array}$ & $\begin{array}{c}\mathrm{Sr} \\
(\mathrm{ppm})\end{array}$ & $\begin{array}{c}\mathrm{Mn} \\
(\mathrm{ppm})\end{array}$ & $\begin{array}{c}\mathrm{Fe} \\
(\mathrm{ppm})\end{array}$ & $\begin{array}{c}\mathrm{Na} \\
(\mathrm{ppm})\end{array}$ & $\begin{array}{c}\mathrm{S} \\
(\mathrm{ppm})\end{array}$ \\
\hline 1 (dark) & 267900 & 113400 & 500 & 100 & 2600 & 100 & 200 \\
& $( \pm 50400)$ & $( \pm 4500)$ & $( \pm 200)$ & $( \pm 100)$ & $( \pm 900)$ & $( \pm 100)$ & $( \pm 100)$ \\
a2 (yellow) & 354900 & 33400 & 1200 & $\mathrm{~B} . \mathrm{D}$. & 1400 & B.D & 200 \\
3 (dark) & 247100 & 112500 & 400 & 300 & 5500 & B.D. & 100 \\
& $( \pm 1600)$ & $( \pm 2800)$ & $( \pm 100)$ & $( \pm 200)$ & $( \pm 500)$ & 100 & $(0)$ \\
4 (dark) & 250900 & 11500 & 400 & 300 & 10500 & 100 & 40 \\
& $( \pm 33200)$ & $( \pm 1900)$ & $( \pm 100)$ & $( \pm 40)$ & $( \pm 2200)$ & $( \pm 100)$ & $( \pm 60)$ \\
\hline
\end{tabular}

Note: B.D. = all values below detection limit for the element.

a Zone 2 had only one data point and, therefore, no standard deviation.

Table 4. Average elemental concentrations of porphyrotopic calcite and the host calcite matrix from Sample 103-639D-5R-2, 124-128 cm (Unit V). Values in parentheses are one standard deviation of the average.

\begin{tabular}{lccccccc}
\hline \multicolumn{1}{c}{ Calcite } & $\begin{array}{c}\mathrm{Ca} \\
(\mathrm{ppm})\end{array}$ & $\begin{array}{c}\mathrm{Mg} \\
(\mathrm{ppm})\end{array}$ & $\begin{array}{c}\mathrm{Sr} \\
(\mathrm{ppm})\end{array}$ & $\begin{array}{c}\mathrm{Mn} \\
(\mathrm{ppm})\end{array}$ & $\begin{array}{c}\mathrm{Fe} \\
(\mathrm{ppm})\end{array}$ & $\begin{array}{c}\mathrm{Na} \\
(\mathrm{ppm})\end{array}$ & $\begin{array}{c}\mathrm{S} \\
(\mathrm{ppm})\end{array}$ \\
\hline Porphyrotopic & 396900 & 3700 & 400 & 100 & 300 & B.D. & $\begin{array}{c}70 \\
\end{array}$ \\
Matrix & $( \pm 2500)$ & $( \pm 1300)$ & $( \pm 300)$ & $( \pm 100)$ & $( \pm 100)$ & & $( \pm 90)$ \\
& 258300 & 4600 & 600 & 80 & 400 & 100 & 300 \\
& $( \pm 59300)$ & $( \pm 1000)$ & $( \pm 300)$ & $( \pm 90)$ & $( \pm 300)$ & $( \pm 200)$ & $( \pm 100)$ \\
\hline
\end{tabular}

Note: B.D. = all values below detection limit for the element.

The magnesium content in the Unit IV baroque dolomite increases away from the host, indicating that the dolomite became more stoichiometric with progressive growth into the open fracture. The increase in iron concentrations that caused dimming of the luminescence in zones 3 and 4 (Figs. 17 and 18 and Table 1 ) is characteristic of burial diagenesis.

Dark luminescent bands rim detrital dolomite and are the last variation in the chemistry of the dolomite lining the wide fractures. The presence of this band on all sides of the detrital dolomite filling the wide fractures may indicate that this last dolomitization event occurred after the internal erosion of the dolomite lining the fractures. However, observations were not conclusive that the dark band is present on all sides because the plane of the thin sections does not provide reliable two-dimensional surfaces to determine the timing of this event.

Ferroan cement precipitation has been attributed to oxygen reduction of pore water through bacterial respiration and oxidation of organic matter (Radke and Mathis, 1980; Scholle and Halley, 1985). These processes may occur with burial, from a few meters or tens of meters below the sediment/water interface (Scholle and Halley, 1985). Similar processes may occur in the tidal flat environment, and reducing brines may be produced (Sears and Lucia, 1980). The possibility that an iron-rich zone formed after the fractures were filled with the internal sediment suggests reducing conditions associated with burial contributed to the formation of iron-rich dolomite.

The clear dolomite lining some of the fractures in the upper strata of Unit IV also exhibits a baroque crystal morphology. The baroque morphology of these crystals, in addition to the mineral pyrolysis results, may also indicate their precipitation from hypersaline brines (Friedman, 1980). Baroque crystals would also be expected to be present in the underlying lower strata of Unit V if they had resulted from burial. Evidence for near-surface hypersaline conditions would instead be expected in the overlying strata of Unit IV. Thus, the presence of baroque crystals in the upper strata of Unit IV and the lack of baroque crystals in the lower strata of Unit V are significant because they in- dicate that the crystals formed as a result of near-surface hypersaline conditions.

The elemental concentrations in the turbid cores of the rhombohedral dolomite in Unit IV (Sample 103-639D-2R, CC [5$7 \mathrm{~cm}$ ) ) also indicate that a hypersaline diagenetic environment is responsible for the dolomitization. Microprobe analyses found variations in the elemental concentrations of the turbid core with areas of high sulfur and iron concentrations (see Fig. 20). The coincidence of high iron and sulfur concentrations may be the result of sulfide mineral inclusions. Highly variable strontium, sulfur, and sodium concentrations in the core (see Fig. 20) may result from the analysis of evaporitic mineral inclusions.

Turbid cores within rhombohedral dolomite result from the incorporation of precursor carbonate, other minerals, fluid inclusions, or a combination of these. The absence of inclusions in the clear rims indicates the following: (1) the initial pore fluids were supersaturated with respect to the minerals present during precipitation of the core (Sibley, 1980), (2) the oxidation of a ferroan core (Katz, 1971), and (3) the clear rims precipitated in a void space that developed as porosity increased with progressive dolomitization (Murray, 1960). Folk and Land (1975) interpret the clear rims as resulting from dolomitizing fluids that were lower in salinity than the fluids that formed the turbid cores.

Manganese concentrations show a distinct symmetry from rim through core to rim (Fig. 20E). The iron concentrations also show a systematic change through the luminescent zones of the clear rim (Fig. 20F). In zone 6, adjacent to the core, the manganese concentration increases whereas the iron concentration decreases. In zone 5 both elements decrease in concentration; they increase in concentration in zone 4. Manganese remains relatively high in zone 3 , but the iron content increases significantly. In zone 2 both elements decrease in concentration; zone 1 shows a significant increase in both elements (Figs. 20E and 20F and Table 2).

The general increase documented for iron and manganese indicates that diagenetic conditions became more reducing as the crystal grew. During shallow burial, the reduced Eh of the pore 
waters will mobilize manganese; further reduction mobilizes iron (Krauskopf, 1967; Hesse, 1986). The increase in manganese from the core to zone 1 is consistent with the changes expected during shallow burial. The decrease in the sulfur content toward the rim is consistent with a burial diagenetic environment. Thus, a shallow burial diagenetic environment is inferred by the elemental concentrations of the zones within the clear rim of the rhombohedral dolomite.

Large intracrystalline voids that were observed with the SEM within the cores of the dolomite indicate the dissolution of precursor mineral inclusions. This dissolution and the precipitation of clear rims may have resulted from a change in the pore-water chemistry (Sibley, 1980). Turbid cores may also be compositionally less stable than the rims (Folk and Land, 1975) and could have subsequently dissolved. Thus, the more stable clear rims would remain, as observed in Sample 103-639C-2R-2, 89$92 \mathrm{~cm}$ (Figs. 12 and 13).

The irregular patch of dolomite analyzed from Unit V (Sample 103-639D-5R-2, 124-128 cm) contains baroque dolomite with intergrown crystal boundaries. Geochemically this dolomite differs significantly from the baroque dolomite lining the fracture in Unit IV (Sample 103-639A-8R, CC [6-11 cm]). The sodium content is greatly depleted in zones 2 and 3 of the dolomite patch in Unit V, whereas the strontium content remains consistently significant (Table 3 ). The manganese and iron concentrations of this dolomite (Table 3 ) are also relatively high in comparison to that of the other dolomite from Unit IV (Tables 1 and 2). The significant drop in the magnesium content in zone 2 (Table 3) may be related to a second fracturing event that is documented petrographically and geochemically in Unit IV. The high iron and relatively high manganese contents associated with the central region (zone 4) of the Unit V dolomite patch indicate that reducing conditions developed (Krauskopf, 1967; Hesse, 1986). Although stylolites may have served as avenues for the dolomitizing fluids present in Unit IV to reach Unit V, they may have formed in response to burial. The stylolites, the baroque nature of the dolomite (Radke and Mathis, 1980; Scholle and Halley, 1985), and the geochemical evidence for reducing conditions indicate that the dolomitization was affected by burial diagenesis, although the fluids may have originated in Unit IV.

In summary, the dolomite within Units IV and V initially formed in a near-surface hypersaline environment. The lack of significant dolomitization of the deeper water strata of Unit III indicates that the initial dolomitization event of the host carbonate rock was associated with near-surface diagenesis rather than late-stage, deep-burial dolomitization. The last stage of dolomitization by hypersaline brines must have occurred after tectonic fracturing, because the fractures are lined with baroque dolomite crystals that have a hypersaline geochemical signature. However, burial diagenesis is evidenced by the increase in manganese and iron concentrations in the later-stage dolomite in Unit IV. Burial dolomitization is also represented in Unit IV by the xenotopic texture (Gregg and Sibley, 1984) of the host dolomite. Deeper burial dolomitization is interpreted to be represented in Unit V by the high iron concentration in the center of the irregular patches of dolomite, the baroque morphology of the crystals, and the association of dolomite exclusively with stylolites.

\section{Tectonic Implications}

Units V and IV are interpreted from seismic-reflection data as forming a tilted fault block. Thus, the units are considered to be pre-rift sediments because they were deposited prior to faulting and rifting of the Newfoundland-Iberian margin during the development of the North Atlantic Basin. Because the units are considered to be pre-rift sediments, their depositional environments would reflect the tectonics of the North Atlantic Iberian margin prior to rifting.
The pre-rift carbonate strata (Units IV and V) indicate that water depth increased on the Iberian margin prior to rifting during the Early Cretaceous. The tectonics associated with rifting controlled the environment of dolomitization and the depositional environment of Unit III. A restricted lagoon environment and the formation of hypersaline brines is interpreted to have resulted from uplift or tilting of the fault block during rifting. The second fracturing event, which is documented in the hypersaline dolomite lining fractures in Unit IV, indicates the subsequent presence of a nearby supratidal environment. Thus, the second fracturing event resulted from continued uplift of the strata. Subsidence after this rifting stage and normal faulting of the strata are represented by the deposition of Unit III.

\section{CONCLUSIONS}

The depositional environments of Units III, IV, and V and the dolomitization of Units IV and V are interpreted to be strongly associated with the tectonics of the Iberian margin. The increase in water depth represented by the depositional environments of Units IV and V was associated with subsidence prior to rifting, whereas the dolomitization of these units in a near-surface hypersaline environment resulted from uplift during rifting. The deposition of Unit III in an upper-slope environment resulted from subsidence and normal faulting during and after rifting.

The dolomitization of Unit V is associated with the stylolites that enclose the irregular patches of dolomite and isolated dolomite rhombohedra. The stylolites may have been avenues for the dolomitization fluids present in Unit IV. Veins of dolomite indicate that fracturing events influenced the dolomitization of this unit. The diagenesis of Unit IV is interpreted to have occurred in six distinct events: (1) dolomitization of the host; (2) fracture of the host; (3) precipitation of clear dolomite, filling the fractures; (4) a second fracturing event, widening some of the filled fractures; (5) continued growth of the clear dolomite in the widened fractures; and (6) infill of the fractures with internal sediment.

The petrographic and geochemical characteristics of the dolomite indicate that the early dolomitizing event was influenced by hypersaline brines developed in an evaporitic, perhaps supratidal, environment. The presence of thoroughly dolomitized strata (Unit IV) overlying partially or not dolomitized strata (Unit V) supports the formation of near-surface dolomitizing fluids. Hypersalinity and evaporite formation are generally considered to be characteristic of uplift during rifting. A shallow or restricted basin associated with uplift during rifting must have developed after the deposition of Units V and IV. Thus, the dolomitization was a product of the shallow or restricted environment that developed during the initiation of rifting of the North Atlantic along the Galicia margin. This environment was conducive to the formation of near-surface hypersaline brines, to the precipitation of evaporites or sulfate minerals, and to the dolomitization of the limestone.

The late-stage dolomite within Units V and IV indicates that burial conditions were also conducive to dolomitization. These stages of dolomite are enriched in manganese and/or iron, which evidences reducing conditions. The stylolites and the baroque nature of the dolomite patches within Unit V, the possible precipitation of ferroan dolomite after the infill of the fractures within Unit IV, and the geochemical evidence for reducing conditions indicate that the later stages of dolomitization occurred during burial diagenesis.

\section{ACKNOWLEDGMENTS}

J. A. Haggerty thanks the Ocean Drilling Program for inviting her to participate on Leg 103. She also thanks her shipmates for the stimulating conversations pertaining to the geologic history of the Galicia margin. The authors thank M. P. Smith for aid with the electron micro- 
probe analyses and Dennis Prezbindowski, H. Holland, and J. Gregg for reviews of a previous version of this manuscript. This research was supported by a grant from the JOI-U.S. Science Advisory Committee.

\section{REFERENCES}

Bein, A., and Land, L. S., 1983. Carbonate sedimentation and diagenesis associated with Mg-Ca-chloride brines: the Permian San Andres Formation in the Texas Panhandle. J. Sediment. Petrol., 53:243-260.

Folk, R. L., and Land, L. S., 1975 . Mg/Ca ratio and salinity: two controls over crystallization of dolomite. AAPG Bull., 59:60-68.

Friedman, G. M., 1965. Terminology of crystallization textures and fabrics in sedimentary rocks. J. Sediment. Petrol., 35:643-655.

1971. Staining. In Carver, R. E. (Ed.), Processes in Sedimentary Petrology: New York (Wiley), 511-530.

1980. Dolomite is an evaporite mineral: evidence from the rock record and from sea-marginal ponds of the Red Sea. In Zenger, D. H., Dunham, J. B., and Ethington, R. L. (Eds.), Concepts and Models of Dolomitization: Spec. Publ. Soc. Econ. Paleontol. Mineral., 28:69-80.

Friedman, G. M., and Radke, B., 1978. Evidence for sabkha overprint and conditions of intermittent emergence in Cambrian-Ordovician carbonates of northeastern North America and Queensland, Australia. Geology, 65:123-145.

Gregg, J. M., and Sibley, D. F., 1984. Epigenetic dolomitization and the origin of xenotopic dolomite texture. J. Sediment. Petrol., 54:908931.

Hardie, L. A., 1987. Dolomitization: a critical view of some current views. J. Sediment. Petrol., 57:166-183.

Hesse, R., 1986. Diagenesis. 11. Early diagenetic pore water/sediment interaction: modern offshore basins. Geosci. Can., 13:165-195.

Illing, L. V., Wells, A. J., and Taylor, J.C.M., 1965. Penecontemporary dolomite in the Persian Gulf. In Pray, L. C., and Murray, R. C., (Eds.), Dolomitization and limestone diagenesis: a symposium. Spec. Publ. Econ. Paleontol. Mineral., 13:89-111.

Jansa, L. F., and Wade, J. A., 1975. Geology of the continental margin off Nova Scotia and Newfoundland. In van der Linden, W.J.M., and Wade, J. A. (Eds.), Offshore Geology of Eastern Canada (Vol. 2): Pap. Geol. Surv. Can., 74-30:51-105.

Katz, A., 1971. Zoned dolomite crystals. J. Geol., 79:38-51.

Krauskopf, K. B., 1967. Introduction to Geochemistry: New York (McGraw-Hill)

Land, L. S., 1980. The isotopic and trace element geochemistry of dolomite: the state of the art. In Zenger, D. H., Dunham, J. B., and
Ethington, R. L. (Eds.), Concepts and Models of Dolomitization: Spec. Publ. Soc. Econ. Paleontol. Mineral., 28:87-110.

Mattes, B. W., and Mountjoy, E. W., 1980. Burial dolomitization of the upper Devonian Miette buildup, Jasper National Park, Alberta. In Zenger, D. H., Dunham, J. B., and Ethington, R. L. (Eds.), Concepts and Models of Dolomitization: Spec. Publ. Soc. Econ. Paleontol. Mineral., 28:259-297.

Murray, R. C., 1960. Origin of porosity in carbonate rocks. J. Sediment. Petrol., 30:59-84.

Pierson, B. J., 1981. The control of cathodoluminescence in dolomite by iron and manganese. Sedimentology, 28:601-610.

'Radke, B. M., and Mathis, R. L., 1980. On the formation and occurrence of saddle dolomite. J. Sediment. Petrol., 50:1149-1168.

Scholle, P. A., and Halley, R. B., 1985. Burial diagenesis: out of sight, out of mind. In Schneidermann, N., and Harris, P. M. (Eds.), Carbonate Cements: Spec. Publ. Soc. Econ. Paleontol. Mineral., 36: 309-334.

Sears, S. O., and Lucia, F. J., 1980. Dolomitization of northern Michigan Niagara reefs by brine refluxion and freshwater/seawater mixing. In Zenger, D. H., Dunham, J. B., and Ethington, R. L. (Eds.), Concepts and Models of Dolomitization: Spec. Publ. Soc. Econ. Paleontol. Mineral., 28:215-236.

Shipboard Scientific Party, 1987. Site 639. In Boillot, G., Winterer, E. L., et al., Proc. ODP, Init. Repts., 103: College Station, TX (Ocean Drilling Program), 409-532.

Sibley, D. F., 1980. Climatic control of dolomitization, Seroe Domi Formation (Pliocene), Bonaire, N. A. In Zenger, D. H., Dunham, J. B., and Ethington, R. L. (Eds.), Concepts and Models of Dolomitization: Spec. Publ. Soc. Econ. Paleontol. Mineral., 28:247-258.

Skinner, H.C.W., 1963. Precipitation of calcian dolomites and magnesium calcites in the southeast of south Australia. Am. J. Sci., 261: 449-472.

Sliter, W. V., 1980. Mesozoic foraminifers and deep-sea benthic environments from Deep Sea Drilling Project Sites 415 and 416, eastern North Atlantic. In Lancelot, Y., Winterer, E. L., et al., Init. Repts. DSDP, 50: Washington (U.S. Govt. Printing Office), 353-428.

Smith, M. P., 1986. Silver coating inhibits electron beam damage of carbonates. J. Sediment. Petrol., 56:560-561.

Wanless, H. R., 1979. Limestone response to stress: pressure solution and dolomitization. J. Sediment. Petrol., 49:437-462.

Date of initial receipt: 14 May 1987

Date of acceptance: 3 February 1988

Ms 103B-123 